\title{
Tetanus Toxin Synthesis is Under the Control of A Complex Network of Regulatory Genes in Clostridium tetani
}

\author{
Diana Chapeton-Montes ${ }^{1}$, Lucile Plourde ${ }^{2} \mathbb{D}$, Cecile Deneve $\left.{ }^{1} \mathbb{(}\right)$, Dominique Garnier ${ }^{2}$, \\ Fabien Barbirato ${ }^{2}$, Vincent Colombié ${ }^{2}$, Sandy Demay ${ }^{2}$, Georges Haustant ${ }^{1}$, Olivier Gorgette ${ }^{3}(\mathbb{D}$, \\ Christine Schmitt ${ }^{3}\left(\mathbb{D}\right.$, Catherine Thouvenot $^{3}$, Holger Brüggemann ${ }^{4}\left(\mathbb{D}\right.$ and Michel R. Popoff ${ }^{1, *(1)}$ \\ 1 Bactéries anaérobies et Toxines, Institut Pasteur, 75724 Paris, France; dianajoanne@gmail.com (D.C.-M.); \\ cecile.deneve-larrazet@u-psud.fr (C.D.); georges.haustant@pasteur.fr (G.H.) \\ 2 Sanofi-Pasteur, 69280 Marcy l’Etoile, France; Lucile.Plourde@sanofi.com (L.P.); \\ Dominique.Garnier@sanofi.com (D.G.); Fabien.Barbirato@sanofi.com (F.B.); \\ Vincent.Colombie@sanofi.com (V.C.); Sandy.Demay@sanofi.com (S.D.) \\ 3 Unité Technologie et Service Bioimagerie Ultrastructurale, Institut Pasteur, 75724 Paris, France; \\ olivier.gorgette@pasteur.fr (O.G.); christine.schmitt@pasteur.fr (C.S.); catherine.thouvenot@pasteur.fr (C.T.) \\ 4 Department of Biomedicine, Aarhus University, 8000 Aarhus, Denmark; brueggemann@biomed.au.dk \\ * Correspondence: popoff2m@gmail.com
}

Received: 20 April 2020; Accepted: 8 May 2020; Published: 15 May 2020

\begin{abstract}
Clostridium tetani produces a potent neurotoxin, the tetanus toxin (TeNT), which is responsible for an often-fatal neurological disease (tetanus) characterized by spastic paralysis. Prevention is efficiently acquired by vaccination with the TeNT toxoid, which is obtained by $C$. tetani fermentation and subsequent purification and chemical inactivation. $C$. tetani synthesizes TeNT in a regulated manner. Indeed, the TeNT gene (tent) is mainly expressed in the late exponential and early stationary growth phases. The gene tet $R$ (tetanus regulatory gene), located immediately upstream of tent, encodes an alternative sigma factor which was previously identified as a positive regulator of tent. In addition, the genome of $C$. tetani encodes more than 127 putative regulators, including 30 two-component systems (TCSs). Here, we investigated the impact of 12 regulators on TeNT synthesis which were selected based on their homology with related regulatory elements involved in toxin production in other clostridial species. Among nine TCSs tested, three of them impact TeNT production, including two positive regulators that indirectly stimulate tent and tet $R$ transcription. One negative regulator was identified that interacts with both tent and tet $R$ promoters. Two other TCSs showed a moderate effect: one binds to the tent promoter and weakly increases the extracellular TeNT level, and another one has a weak inverse effect. In addition, CodY (control of dciA (decoyinine induced operon) Y) but not Spo0A (sporulation stage 0) or the DNA repair protein Mfd (mutation frequency decline) positively controls TeNT synthesis by interacting with the tent promoter. Moreover, we found that inorganic phosphate and carbonate are among the environmental factors that control TeNT production. Our data show that TeNT synthesis is under the control of a complex network of regulators that are largely distinct from those involved in the control of toxin production in Clostridium botulinum or Clostridium difficile.
\end{abstract}

Keywords: Clostridium tetani; Clostridium botulinum; tetanus toxin; two-component system; gene transcription

Key Contribution: Tetanus toxin synthesis is under the control of a complex network of regulation linked to the metabolism in Clostridium tetani including at least two positive and one negative two-component system regulators and the master regulator of metabolism CodY. Inorganic phosphate and carbonate are environmental factors involved in the control of tetanus toxin synthesis. 


\section{Introduction}

Clostridium tetani is an environmental Gram-positive, spore-forming and anaerobic rod-shaped bacterium which synthesizes a potent neurotoxin, the tetanus toxin (TeNT) [1]. C. tetani spores can enter an organism through an open wound. Spores germinate and C. tetani grows in anaerobic conditions in necrotic tissues. TeNT is synthesized at the end of the exponential growth phase and is released in the surrounding tissues. TeNT specifically recognizes nidogens at the neuromuscular junctions [2], and enters motorneurons. TeNT is retrogradely transported to the central nervous system. Then, TeNT enters inhibitory interneurons and blocks the release of neurotransmitters (glycine, GABA (gamma-aminobutyric acid)) upon proteolytic cleavage of the SNARE (soluble N-ethylmaleimide-sensitive factor attachment protein receptor) protein VAMP2 (vesicle associated membrane protein) [3,4].

Vaccination based on the TeNT toxoid is a very efficient prevention measure against tetanus. It is noteworthy that in addition to the use as a single-antigen vaccine for specific prevention of tetanus, the TeNT toxoid is combined with other vaccine antigens for protection against other infectious diseases [5]. Industrial TeNT production is obtained by fermentation of $C$. tetani clinical isolates. TeNT is then extracted from culture supernatants and inactivated with formalin. C. tetani fermentation is a critical and complex step in vaccine production as it is performed in a rich growth medium under a strictly controlled environment. The essential medium components such as amino acids that result in a high TeNT yield are partially identified. Thus, the toxin yield varies with different media and charges [6].

The TeNT gene (tent) is located on a large plasmid in C. tetani $[7,8]$. The first complete genome sequence of a toxigenic C. tetani strain (E88) was determined in 2003 [9]. The genome contains a chromosome of approximately $2.8 \mathrm{Mb}$ and a TeNT-encoding plasmid of $74 \mathrm{~kb}$. The genomes of additional $C$. tetani strains have been sequenced and showed that the plasmid-encoded tent is highly conserved [10-12]. A conserved gene (tet $R$, tetanus toxin regulatory gene) just upstream of tent encodes for an alternative sigma factor which positively regulates the transcription of tent [13]. TetR is homologous to BotR (botulinum toxin regulator) which controls the synthesis of the botulinum neurotoxin (BoNT) in Clostridium botulinum A, B, C and D [14]. TetR and BotR belong with Clostridium difficile TcdR (or TxeR) (Clostridium difficile toxin regulator) and Clostridium perfringens UviA (UV-inducible gene A) to a sub-group of the sigma 70 family of RNA polymerase sigma factors which control clostridial toxin gene syntheses $[15,16]$. However, the regulatory network governing TeNT synthesis is still poorly understood. A better knowledge of the regulatory mechanisms of TeNT synthesis in C. tetani and determination of the environmental factors controlling this regulation are required for improving toxin production.

To successfully respond to changes in different environmental conditions and to regulate virulence, many bacteria use a complex regulatory network involving diverse types of molecules, including RNA, DNA, proteins and metabolites. Among these are global regulators like two-component systems (TCS) and CodY to sense the relevant environmental signals $[17,18]$. TCSs are ubiquitous among bacteria. They consist of a membrane-bound or cytosolic sensor histidine kinase (SHK) that senses a stimulus and its cytoplasmic cognate response regulator (RR) that mediates the cellular response. Following a specific stimulus, the SHK autophosphorylates at a conserved histidine residue. The phosphoryl group is then transferred from the histidine to a conserved aspartate residue in the RR, which upon phosphorylation is able to control the expression of its target genes [18].

Depending on the availability of nutrients, bacteria have to adjust their gene expression. The global regulator CodY has been shown to be an important regulatory link between metabolism and virulence factor synthesis in many low G + C Gram-positive bacteria. CodY displays enhanced affinity for its DNA target when bound to GTP and/or branched-chain amino acids [19]. In C. botulinum ATCC 3502 , CodY has been shown to positively regulate bont expression, and to bind to the promoter of the $n t n h$-bont $A$ operon in a GTP-dependent manner [20]. In addition, the sporulation regulator Spo0A has been found to positively regulate BoNT synthesis in C. botulinum type E, which is part of the group II 
of C. botulinum and lacks BotR. Spo0A binds to the promoter of the bont/E operon and enhances its transcription [21]. Spo0A is expressed in the exponential growth phase of $C$. botulinum and initiates the cascade of alternative sigma factors involved in sporulation [22]. However, Spo0A targets several hundred other genes and has pleiotropic effects [23]. Moreover, the mutation frequency decline ( $m f d)$ gene, which encodes a transcription-coupled repair factor, also shows pleiotropic effects: it increases the expression of both Toxin A and Toxin B-encoding genes in C. difficile [24]. These genes codY, spo0A and $m f d$ are conserved in the $C$. tetani genome.

Genomic analysis of the $C$. tetani strain E88 reveals the presence of numerous putative regulatory genes, some of them being homologous to regulatory genes in other clostridia or bacteria. The aim of this work was to determine the role of 12 putative regulatory systems in TeNT synthesis, nine two-component systems as well as the global regulators CodY, Spo0A and Mfd.

\section{Results}

\subsection{Genomic Analysis of Regulatory Genes in C. tetani}

Genome sequencing of strain E88 showed that the large tent-containing plasmid also harbors regulatory elements: tet $R$ located immediately upstream of tent, a two-component system (TCS) (CTC_RS13805/CTC_RS13810, previously named ctp21/ctp22) homologous to systems in other Gram-positive bacteria including C. botulinum and Bacillus sp., and three additional putative sigma factors [9]. In addition, refined genomic analysis showed that the chromosome of strain E88 possesses 30 TCSs based on the conserved motifs of histidine kinase as part of the SHK and a receiver domain Rec as part of the adjacent RR. Most of the 30 TCSs belong to the OmpR (outer membrane protein regulator) family (19 TCSs), two to (lytic gene regulator/alginate biosynthesis regulator) LytR/AlgR, two to (nitrate reductase regulator) NarL, two to (factor for inversion stimulation) Fis, one to (L-arabinose gene regulator) $\mathrm{AraC}$, one to (purine catabolic gene regulator) PucR, one to LysR (lysine synthesis regulator) and one to XRE ((prophage Bacillus subtilis) PBSX repressor) families (Table 1). All 30 TCSs except one share homology with putative TCSs in other clostridia species. Among them, 19 TCSs are homologous to related genes in C. botulinum strain Hall (identity level $\geq 45 \%$ ) (Table 1). It was previously shown that five TCSs in strain Hall positively regulate botulinum neurotoxin (BoNT) synthesis [25]. Two of them are homologous to C. tetani TCSs, i.e., CLC0661/CLC0663 from C. botulinum with $65 \%$ protein identity to CTC_RS02080/CTC_RS02085 of C. tetani and CLC0410/CLC0411 shows 68\% protein identity to CTC_RS10030/CTC_RS10035 (Table 1). Another study identified one TCS (CB00786/CB00787) in C. botulinum strain ATCC3502, that negatively regulates bont gene expression [26]. This TCS shares significant identity with a C. tetani TCS (CTC_RS07310/CTC_RS07315).

The genome of $C$. tetani strain CN655 [10] shares the same TCS genes as strain E88. Since we have already characterized the tet $R$ in strain $\mathrm{CN} 655$, a strain which is more easily transformable compared to other $C$. tetani strains under the applied conditions, the strain $\mathrm{CN} 655$ was selected for further genetic investigations including the analysis of nine TCS genes, $m f d$, spo0A and $\operatorname{cod} Y$.

Res, respiration; Bac, bacitracin; Vir, virulence; Spa, subtilin gene; Van, vancomycin; Gtc, gramicidin transcription; Arc, aerobic respiration control; Pho, phosphate; Feu, ferric uptake; Dcu, dicarboxylate uptake; Sin, sporulation inhibition; Eut, ethanolamine utilization; Ato, acetoacetyl-coenzyme A transferase. 
Table 1. Two component system (TCS) genes encoded in the genome of C. tetani E88 and their homology with regulatory genes in other clostridia. The recombinant RNA antisense plasmids targeting TCS genes are indicated in column 1. Genetic environment indicates functional genes in close proximity of TCS in C. tetani E88.

\begin{tabular}{|c|c|c|c|c|c|c|c|c|c|c|c|c|c|}
\hline \multirow{2}{*}{$\begin{array}{l}\text { Recombinant } \\
\text { Antisense } \\
\text { mRNA } \\
\text { Plasmid }\end{array}$} & \multicolumn{2}{|c|}{$\begin{array}{l}\text { Gene Bank Accession } \\
\text { Number }\end{array}$} & \multirow{2}{*}{$\begin{array}{l}\text { Other } \\
\text { Gene } \\
\text { Name }\end{array}$} & \multirow[t]{2}{*}{ Role } & \multirow[b]{2}{*}{ Familly (RR) } & \multirow[b]{2}{*}{ Genetic Environment } & \multirow[b]{2}{*}{ Homology } & \multirow{2}{*}{$\begin{array}{l}\text { Homologs (RR) in Other Clostridia } \\
\quad \text { (Protein Identity > 60\%) }\end{array}$} & \multicolumn{3}{|c|}{ Homolog TCS in C. botulinum strain Hall } & \multicolumn{2}{|c|}{$\begin{array}{c}\text { Homolog TCS in } \\
\text { C. botulinum Strain ATCC } \\
3502\end{array}$} \\
\hline & $\begin{array}{l}\text { Old Locus } \\
\text { Tag }\end{array}$ & Locus Tag & & & & & & & $\begin{array}{c}\text { Homolog System } \\
\text { (RR/SHK) }\end{array}$ & $\begin{array}{c}\text { Protein } \\
\text { Identity } \\
(\mathbf{R R})\end{array}$ & $\begin{array}{l}\text { Regulation } \\
\text { of Botulism } \\
\text { Neurotoxin }\end{array}$ & $\begin{array}{c}\text { Homolog } \\
\text { System } \\
\text { (RR/SHK) }\end{array}$ & $\begin{array}{l}\text { Protein } \\
\text { Identity/ } \\
\text { Positive }\end{array}$ \\
\hline & \multicolumn{13}{|c|}{ chromosomal localization } \\
\hline & $\begin{array}{l}\text { CTC_00189 } \\
\text { CTC_00191 }\end{array}$ & $\begin{array}{l}\text { CTC_RS00820 } \\
\text { CTC_RS00825 }\end{array}$ & & $\begin{array}{c}\text { RR } \\
\text { SHK }\end{array}$ & OmpR & Periplasmic endopeptidase & ResD, respiration control & $\begin{array}{l}\text { C. botulinum, C. cochlearium, } \\
\text { C. tetanomorphum, C. scatologenes, C. } \\
\text { drakei, C. magnum, C. sporogenes, } \\
\text { C. tyrobutyricum, C. acetireducens, } \\
\text { C. lijungdahlii, C. novyi, } \\
\text { C. pasteurianum, }\end{array}$ & CLC_3521/CLC_3520 & $81 \%$ & None & $\begin{array}{l}\text { CBO3543 } \\
\text { CBO3542 }\end{array}$ & $\begin{array}{l}81 / 87 \\
67 / 73\end{array}$ \\
\hline & $\begin{array}{l}\text { CTC_00392 } \\
\text { CTC_00393 }\end{array}$ & $\begin{array}{l}\text { CTC_RS01985 } \\
\text { CTC_RS01990 }\end{array}$ & & $\begin{array}{c}\text { RR } \\
\text { SHK }\end{array}$ & OmpR & ABC Transporter & $\begin{array}{l}\text { BacS/BacR regulation of } \\
\text { resistance to bacitracin }\end{array}$ & $\begin{array}{l}\text { C. botulinum, C. tetanomorophum, } \\
\text { C. sporogeneses, . lundense, } \\
\text { C. cavendishii, C. acetobutylicum, } \\
\text { C. pasteurianum, C. ljungdahliii }\end{array}$ & CLC_0331/CLC_0332 & $90 \%$ & None & $\begin{array}{l}\text { CBO0272 } \\
\text { CBO2273 }\end{array}$ & $\begin{array}{l}90 / 92 \\
86 / 89\end{array}$ \\
\hline \multirow[t]{9}{*}{ p1308 } & $\begin{array}{l}\text { CTC_00411 } \\
\text { CTC_00412 }\end{array}$ & $\begin{array}{l}\text { CTC_RS02080 } \\
\text { CTC_RS02085 }\end{array}$ & $\begin{array}{l}\text { phoP } \\
\text { phoR }\end{array}$ & $\begin{array}{c}\text { RR } \\
\text { SHK }\end{array}$ & OmpR & hydroxylamne reductase & $\begin{array}{l}\text { VirI/VirJ regulation of toxin } \\
\text { synthesis }\end{array}$ & $\begin{array}{l}\text { C. botulinum, C. perfringens, } \\
\text { C. carboxidivorans, C. pasteurianum, } \\
\text { C. lundense, C. novyi, C. septicum }\end{array}$ & CLC_0661/CLC_0663 & $65 \%$ & Positive & $\begin{array}{l}\text { CBO0607 } \\
\text { CBO0608 }\end{array}$ & $\begin{array}{l}64 / 72 \\
46 / 55\end{array}$ \\
\hline & $\begin{array}{l}\text { CTC_00455 } \\
\text { CTC_00456 }\end{array}$ & $\begin{array}{l}\text { CTC_RSO2330 } \\
\text { CTC_RS14405 }\end{array}$ & & $\begin{array}{c}\text { RR } \\
\text { SHK }\end{array}$ & & $\begin{array}{l}\text { phosphomannomutase/ } \\
\text { phosphoglucomutase }\end{array}$ & putative rRNA methylase & $\begin{array}{l}\text { C. tetanomorphum, C. ljungdahlii, C. } \\
\text { homopropionicum }\end{array}$ & CLC_0413 & $55 \%$ & unknown & $\begin{array}{l}\text { CBO0355 } \\
\text { no }\end{array}$ & $54 / 59$ \\
\hline & $\begin{array}{l}\text { CTC_00597 } \\
\text { CTC_00598 }\end{array}$ & $\begin{array}{l}\text { CTC_RSO2990 } \\
\text { CTC_RS02995 }\end{array}$ & & $\begin{array}{l}\mathrm{RR} \\
\mathrm{SHK}\end{array}$ & OmpR & Glycerine-deshydrogenase & $\begin{array}{l}\text { BacR regulation of resistance to } \\
\text { bacitracin }\end{array}$ & $\begin{array}{l}\text { C. lundense, C. tetanomorphum, } \\
\text { C. ljungdahlii, C. argetinense, C. drakei }\end{array}$ & CLC_2212/CLC_2211 & $45 \%$ & None & $\begin{array}{l}\text { several } \\
\text { no }\end{array}$ & $45 / 66$ \\
\hline & $\begin{array}{l}\text { CTC_00628 } \\
\text { CTC_00629 }\end{array}$ & $\begin{array}{l}\text { CTC_RS03125 } \\
\text { CTC_RS03130 }\end{array}$ & $\begin{array}{l}\text { spaR } \\
\text { spaK }\end{array}$ & $\begin{array}{c}\text { RR } \\
\text { SHK }\end{array}$ & OmpR & $\begin{array}{l}\text { ABC Transporter SpaEFG: } \\
\text { export subtiline }\end{array}$ & $\begin{array}{l}\text { SpaR/SpaK regulation of } \\
\text { resistance to subtilin }\end{array}$ & $\begin{array}{l}\text { C. botulinum, C. novyi, C. beijerinckii, } \\
\text { C. saccharobutylicum, C. butyricum, } \\
\text { C. sporogenes }\end{array}$ & CLC_1615/CLC_1616 & $65 \%$ & unknown & $\begin{array}{l}\text { CBO1585 } \\
\text { CBO1586 }\end{array}$ & $\begin{array}{l}65 / 69 \\
37 / 43\end{array}$ \\
\hline & $\begin{array}{l}\text { CTC_00805 } \\
\text { CTC_00806 }\end{array}$ & $\begin{array}{l}\text { CTC_RS04010 } \\
\text { CTC_RS04015 }\end{array}$ & & $\begin{array}{c}\text { RR } \\
\text { SHK }\end{array}$ & OmpR & Protein transport & $\begin{array}{l}\text { VanR/VanS regulation of } \\
\text { resistance to vancomycin }\end{array}$ & $\begin{array}{l}\text { C. botulinum, C. cochlearium, } \\
\text { C. tetanomorphum, C. lundens, } \\
\text { C. carboxidivorans, C. sporogenes, } \\
\text { C. pasteurianum }\end{array}$ & CLC_0423/CLC_0424 & $76 \%$ & None & $\begin{array}{l}\text { CBO0365 } \\
\text { CBO0366 }\end{array}$ & $\begin{array}{l}78 / 82 \\
44 / 50\end{array}$ \\
\hline & CTC_00848 & CTC_RS04235 & & $\mathrm{RR}$ & \multirow{2}{*}{ OmpR } & \multirow{2}{*}{ Heat shock protein } & \multirow{2}{*}{$\begin{array}{l}\text { Gtcs/GtcR regulation of antibiotic } \\
\text { synthesis (gramicidin) }\end{array}$} & \multirow{2}{*}{$\begin{array}{l}\text { C. lundense, C. tetanomorphum, } \\
\text { C. amylolyticum, C. perfringens }\end{array}$} & \multirow{2}{*}{ CLC_1640/CLC_1639 } & \multirow{2}{*}{$48 \%$} & \multirow{2}{*}{ None } & several & $47 / 55$ \\
\hline & CTC_00849 & CTC_RS04240 & & SHK & & & & & & & & \multicolumn{2}{|l|}{ no } \\
\hline & $\begin{array}{l}\text { CTC_00872 } \\
\text { CTC_00873 }\end{array}$ & $\begin{array}{l}\text { CTC_RS04365 } \\
\text { CTC_RS04370 }\end{array}$ & & $\begin{array}{l}\text { RR } \\
\text { SHK }\end{array}$ & OmpR & Efflux-ATPase Copper & $\begin{array}{c}\text { Arc, regulation of } \\
\text { aerobic/anaerobic respiration }\end{array}$ & $\begin{array}{l}\text { C. botulinum, C. tetanomorphum, } \\
\text { C. lundense, C. sporogenes, } \\
\text { C. pasteurianum, C. bieierinckii, } \\
\text { C. ljungdahlii }\end{array}$ & CLC_1088/CLC_1089 & $68 \%$ & None & $\begin{array}{l}\text { CBO1035 } \\
\text { CBO1036 }\end{array}$ & $\begin{array}{l}66 / 71 \\
55 / 63\end{array}$ \\
\hline & $\begin{array}{l}\text { CTC_00924 } \\
\text { CTC_00925 }\end{array}$ & $\begin{array}{l}\text { CTC_RS04645 } \\
\text { CTC_RS04650 }\end{array}$ & & $\begin{array}{c}\text { SHK } \\
\text { RR }\end{array}$ & PucR & Zn-dependent protease & $\begin{array}{l}\text { regulation of purine catabolism, } \\
\text { methyl-accepting chemotaxis } \\
\text { protein }\end{array}$ & \multicolumn{4}{|c|}{ No } & $\begin{array}{l}\text { CBO1773 } \\
\text { no }\end{array}$ & $43 / 50$ \\
\hline p1309 & $\begin{array}{l}\text { CTC_00934 } \\
\text { CTC_00935 } \\
\text { CTC_00949 }\end{array}$ & $\begin{array}{l}\text { CTC_RSO4705 } \\
\text { CTC_RS04710 } \\
\text { CTC_RS04780 }\end{array}$ & virS & $\begin{array}{l}\text { SHK } \\
\text { RR } \\
\text { SHK }\end{array}$ & \multirow[t]{2}{*}{$\begin{array}{c}\text { AraC } \\
\text { LytR/AlgR }\end{array}$} & \multirow{2}{*}{$\begin{array}{l}\text { amihydrolase; Pyruvate } \\
\text { formate lyase } \\
\text { transcriptional regulator, } \\
\text { merR family; putative } \\
\text { methyl-accepting } \\
\text { chemotaxis protein } \\
\end{array}$} & \multirow[t]{2}{*}{$\begin{array}{l}\text { LytS, autolysis regulation } \\
\text { virulence regulation }\end{array}$} & \multirow[t]{2}{*}{$\begin{array}{l}\text { C. botulinum B str. Eklund 17B, } \\
\text { C. novyi } \\
\text { C. butyricum, C. septicum }\end{array}$} & \multirow[t]{2}{*}{$\begin{array}{c}\text { CLC_1627 } \\
\text { CLC_1105/CLC_1104 }\end{array}$} & \multirow[t]{2}{*}{$\begin{array}{l}41 \% \\
35 \%\end{array}$} & \multirow[t]{2}{*}{$\begin{array}{l}\text { unknown } \\
\text { None }\end{array}$} & $\begin{array}{l}\text { no } \\
\text { no } \\
\text { no }\end{array}$ & \\
\hline p1310 & CTC_00950 & CTC_RS04785 & virR & $\mathrm{RR}$ & & & & & & & & СВO1053 & $35 / 54$ \\
\hline
\end{tabular}


Table 1. Cont.

\begin{tabular}{|c|c|c|c|c|c|c|c|c|c|c|c|c|c|}
\hline \multirow{2}{*}{$\begin{array}{l}\text { Recombinant } \\
\text { Antisense } \\
\text { mRNA } \\
\text { Plasmid }\end{array}$} & \multicolumn{2}{|c|}{$\begin{array}{l}\text { Gene Bank Accession } \\
\text { Number }\end{array}$} & \multirow{2}{*}{$\begin{array}{l}\text { Other } \\
\text { Gene } \\
\text { Name }\end{array}$} & \multirow[t]{2}{*}{ Role } & \multirow[b]{2}{*}{ Familly (RR) } & \multirow[b]{2}{*}{ Genetic Environment } & \multirow[b]{2}{*}{ Homology } & \multirow{2}{*}{$\begin{array}{l}\text { Homologs (RR) in Other Clostridia } \\
\quad \text { (Protein Identity }>60 \%)\end{array}$} & \multicolumn{3}{|c|}{ Homolog TCS in C. botulinum strain Hall } & \multicolumn{2}{|c|}{$\begin{array}{c}\text { Homolog TCS in } \\
\text { C. botulinum Strain ATCC } \\
3502\end{array}$} \\
\hline & $\begin{array}{l}\text { Old Locus } \\
\text { Tag }\end{array}$ & Locus Tag & & & & & & & $\begin{array}{c}\text { Homolog System } \\
\text { (RR/SHK) }\end{array}$ & $\begin{array}{l}\text { Protein } \\
\text { Identity } \\
\text { (RR) }\end{array}$ & $\begin{array}{l}\text { Regulation } \\
\text { of Botulism } \\
\text { Neurotoxin }\end{array}$ & $\begin{array}{c}\text { Homolog } \\
\text { System } \\
\text { (RR/SHK) }\end{array}$ & $\begin{array}{l}\text { Protein } \\
\text { Identity/ } \\
\text { Positive }\end{array}$ \\
\hline & \multicolumn{13}{|c|}{ chromosomal localization } \\
\hline p1311 & $\begin{array}{l}\text { CTC_01130 } \\
\text { CTC_01131 }\end{array}$ & $\begin{array}{l}\text { CTC_RS05745 } \\
\text { CTC_RS05750 }\end{array}$ & phoR & $\begin{array}{l}\text { RR } \\
\text { SHK }\end{array}$ & OmpR & ABC Transporteur: phosphates & $\begin{array}{l}\text { PhoP/PhoR, regulation of } \\
\text { phosphate uptake }\end{array}$ & $\begin{array}{l}\text { C. lundense, C. carboxidivorans, } \\
\text { C. ljungdahlii, C. botulinum, } \\
\text { C. sporogenenes, C. butyricum, } \\
\text { C. accobutylicum, ,. butyricum, } \\
\text { C. pasteurianum, C. neonatale, C. baratii }\end{array}$ & CLC_2386/CLC_2385 & $73 \%$ & None & $\begin{array}{l}\text { CBO2527 } \\
\text { CBO2526 }\end{array}$ & $\begin{array}{l}73 / 87 \\
52 / 75\end{array}$ \\
\hline p1312 & $\begin{array}{l}\text { CTC_01211 } \\
\text { CTC_01212 }\end{array}$ & $\begin{array}{l}\text { CTC_RS06180 } \\
\text { CTC_RS06185 }\end{array}$ & tpA & $\begin{array}{c}\text { SHK } \\
\text { RR }\end{array}$ & LysR & anaerobic sulfite reductase & $\begin{array}{l}\text { LytR, autolysis regulation, } \\
\text { methyl-accepting chemotaxis } \\
\text { protein tlpA }\end{array}$ & C. cochlearium & CLC_3570 & $35 \%$ & unknown & $\begin{array}{l}\text { CBO2828 } \\
\text { several }\end{array}$ & $\begin{array}{l}36 / 61 \\
35 / 57\end{array}$ \\
\hline \multirow[t]{11}{*}{ p1419 } & $\begin{array}{l}\text { CTC_01420 } \\
\text { CTC_01421 }\end{array}$ & $\begin{array}{l}\text { CTC_RSO7310 } \\
\text { CTC_RS07315 }\end{array}$ & resE & $\begin{array}{c}\text { SHK } \\
\text { RR }\end{array}$ & OmpR & ABC Transporter & $\begin{array}{l}\mathrm{YycG} / \mathrm{YycF} \text {, regulation of cell } \\
\text { division }\end{array}$ & $\begin{array}{l}\text { C. lundense, C. celluloovorans, } \\
\text { C. amylolyticum, C. botulinum, }\end{array}$ & $\begin{array}{l}\text { CLC_0842/CLC_08433 } \\
\text { CB00786/CB00787** }\end{array}$ & $58 \%$ & $\begin{array}{c}\text { None } \\
\text { Negative }\end{array}$ & $\begin{array}{l}\text { CBO0787 } \\
\text { СВO0786 }\end{array}$ & $\begin{array}{l}47 / 65 \\
58 / 76\end{array}$ \\
\hline & $\begin{array}{l}\text { CTC_01481 } \\
\text { CT_01482 }\end{array}$ & $\begin{array}{l}\text { CTC_RS07700 } \\
\text { CTC_RS07705 }\end{array}$ & & $\begin{array}{c}\text { SHK } \\
\text { RR }\end{array}$ & OmpR & $\begin{array}{l}\text { Conserved proteins with } \\
\text { transmembrane helices and } \\
4 \mathrm{~F} e 4 \mathrm{~S} \text { motif }\end{array}$ & $\begin{array}{l}\text { FeuQ/FeuP, regulation of iron } \\
\text { acquisition }\end{array}$ & C. noovi, C. yurii & CLC_3521/CLC_3520 & $43 \%$ & None & $\begin{array}{l}\text { no } \\
\text { several }\end{array}$ & $43 / 60$ \\
\hline & $\begin{array}{l}\text { CTC_01490 } \\
\text { CTC_01491 }\end{array}$ & $\begin{array}{l}\text { CTC_RS07755 } \\
\text { CTC_RS07760 }\end{array}$ & & $\begin{array}{c}\text { RR } \\
\text { SHK }\end{array}$ & OmpR & $\begin{array}{c}\text { Heat shock protein HtpG } \\
\text { (chaperonne); Membrane protein }\end{array}$ & unknown & $\begin{array}{l}\text { C. lundense, C. tetanomorphum, } \\
\text { C. kluyveri, C. pasteurianum, } \\
\text { C. carboxidivorans, C. ljungdahlii, } \\
\text { C. tyrobutyricum, C. acetobutylicum }\end{array}$ & CLC_0423/CLC_0424 & $44 \%$ & None & $\begin{array}{l}\text { several } \\
\text { no }\end{array}$ & $44 / 64$ \\
\hline & $\begin{array}{l}\text { CTC_01523 } \\
\text { CTC_01524 }\end{array}$ & $\begin{array}{l}\text { CTC_RS07895 } \\
\text { CTC_RS07900 }\end{array}$ & dpiB & $\begin{array}{l}\text { RR } \\
\text { SHK }\end{array}$ & NarL & $\begin{array}{l}\text { Fumarate-reductase soluble } \\
\text { flavoprotein }\end{array}$ & $\begin{array}{l}\text { DcuR, regulation of fumarate } \\
\text { anaerobic respiration through } \\
\text { C4-dicarboxylates }\end{array}$ & C. cochlearium & CLC_0307/CLC_0306 & $48 \%$ & None & $\begin{array}{l}\text { CBO0249 } \\
\text { CBO248 }\end{array}$ & $\begin{array}{l}48 / 69 \\
41 / 60\end{array}$ \\
\hline & $\begin{array}{l}\text { CTC_01804 } \\
\text { CTC_01805 }\end{array}$ & $\begin{array}{l}\text { CTC_RSO9305 } \\
\text { CTC_RS09310 }\end{array}$ & & $\begin{array}{c}\text { SHK } \\
\text { RR }\end{array}$ & OmpR & ABC Transporter & $\begin{array}{l}\text { BacS/BacR, AB-Bacitracine } \\
\text { synthesis and regulation }\end{array}$ & $\begin{array}{l}\text { C. tetanomorphum, C. lundense, } \\
\text { C. novyi }\end{array}$ & CLC_2212/CLC_2211 & $56 \%$ & None & $\begin{array}{l}\text { CBO2284 } \\
\text { CBO2285 }\end{array}$ & $\begin{array}{l}47 / 72 \\
56 / 79\end{array}$ \\
\hline & $\begin{array}{l}\text { CTC_01818 } \\
\text { CTC_01819 }\end{array}$ & $\begin{array}{l}\text { CTC_RSO9380 } \\
\text { CTC_RS09385 }\end{array}$ & resE & $\begin{array}{l}\text { SHK } \\
\text { RR }\end{array}$ & OmpR & $\begin{array}{l}\text { ABC Transporter; RNA } \\
\text { polymerase sigma factor }\end{array}$ & unknown & $\begin{array}{l}\text { C. tetanomorphum, C. lundense, } \\
\text { C. lijngdahlii, C. cavendishii }\end{array}$ & $\begin{array}{l}\text { CLC_0842//CLC_08433 } \\
\text { CB00786/CB00787*7 }\end{array}$ & $51 \%$ & $\begin{array}{c}\text { None } \\
\text { Negative }\end{array}$ & $\begin{array}{l}\text { CBO0787 } \\
\text { СBO0786 }\end{array}$ & $\begin{array}{l}38 / 63 \\
51 / 71\end{array}$ \\
\hline & CTC_01848 & CTC_RS14320 & yesM & SHK & NarL/FixJ & Fumarate-reductase & unknown & C. cochlearium & CLC_2236/CLC_2235 & $26 \%$ & None & no & \\
\hline & CTC_01849 & CTC_RS09510 & & $\mathrm{RR}$ & & & & & & & & no & \\
\hline & $\begin{array}{l}\text { CTC_01857 } \\
\text { CTC_01858 }\end{array}$ & $\begin{array}{l}\text { CTC_RS09550 } \\
\text { CTC_RS09555 }\end{array}$ & $\sin R$ & $\begin{array}{c}\text { SHK } \\
\text { RR }\end{array}$ & XRE & Helicase, oleate hydratase & $\begin{array}{l}\text { SinR regulation of entry in } \\
\text { stationary phase, to nutrient } \\
\text { depletion; Spo0A repressor }\end{array}$ & $\begin{array}{l}\text { C. botulinum CDC_69094, C. magnum, } \\
\text { C. beijerinckii }\end{array}$ & No & & & $\begin{array}{l}\text { CBO0693 } \\
\text { no }\end{array}$ & $48 / 70$ \\
\hline & $\begin{array}{l}\text { CTC_01905 } \\
\text { CTC_01906 }\end{array}$ & $\begin{array}{l}\text { CTC_RS09790 } \\
\text { CTC_RS09795 }\end{array}$ & & $\begin{array}{c}\text { SHK } \\
\text { RR }\end{array}$ & OmpR & $\mathrm{ABC}$ Transporter & $\begin{array}{l}\text { BacR; VanR (synthèse et } \\
\text { régulation AB) }\end{array}$ & C. indolis, C. methoxybenzovorans & CLC_0423/CLC_0424 & $45 \%$ & None & $\begin{array}{l}\text { no } \\
\text { СвO0365 }\end{array}$ & $45 / 66$ \\
\hline & $\begin{array}{l}\text { CTC_01918 } \\
\text { CTC_01919 }\end{array}$ & $\begin{array}{l}\text { CTC_RS09860 } \\
\text { CTC_RS09865 }\end{array}$ & resE & $\begin{array}{l}\text { SHK } \\
\text { RR }\end{array}$ & OmpR & ABC Transporter & $\begin{array}{l}\text { BacR; VanR (synthèse et } \\
\text { régulation AB) }\end{array}$ & $\begin{array}{l}\text { C. kluyveri, C. uliginosum, C. puniceum, } \\
\text { C. scatologenes, , . saccharoubtylicum, } \\
\text { C. oryzae, C. ljungdahlii, C. lundense, C. } \\
\text { drakey, C. botulinum B2 331, } \\
\text { C. sporogenes, C. acetobutylicum, } \\
\text { C. butyricum }\end{array}$ & $\begin{array}{l}\text { CLC_0842/CLC_0843 } \\
\text { СВ00786/CB00787** }\end{array}$ & $42 \%$ & $\begin{array}{l}\text { None } \\
\text { Negative }\end{array}$ & $\begin{array}{l}\text { CBO0787 } \\
\text { CBO0786 }\end{array}$ & $\begin{array}{l}32 / 53 \\
42 / 60\end{array}$ \\
\hline
\end{tabular}


Table 1. Cont.

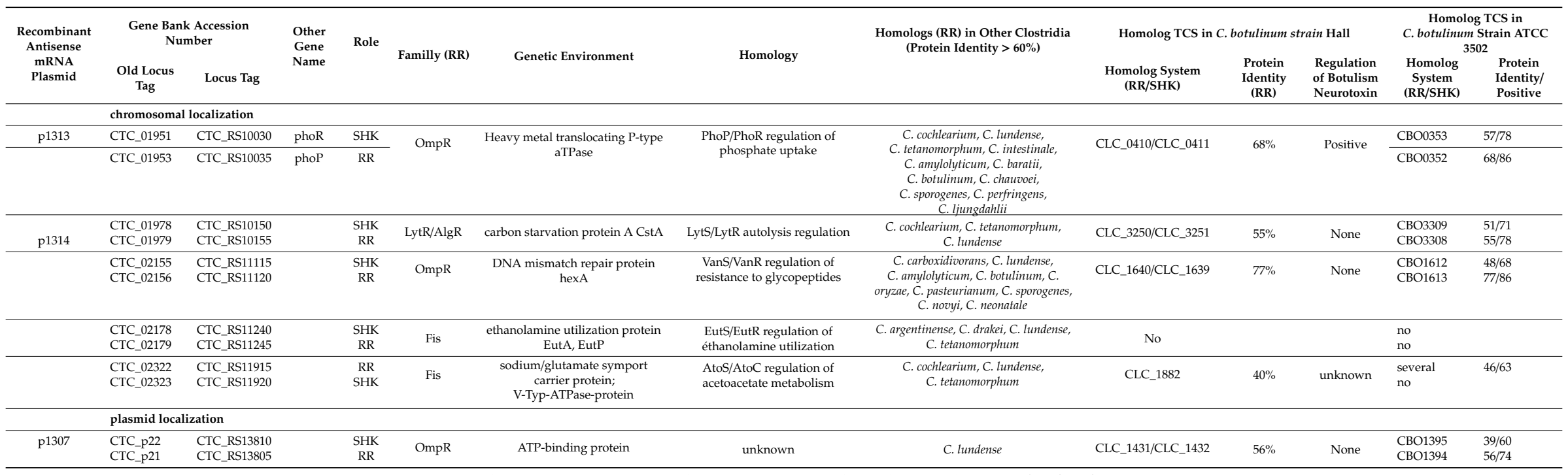

RR, Response Regulator; SHK, Sensor Histidine Kinase, ${ }^{*} 100 \%$ homology with TCSs of C. botulinum ATCC3502. 


\subsection{Construction of TCS Anti-Sense Strains}

Plasmids that were able to generate anti-sense mRNA from nine TCS genes, as well as from $m f d$, spo0A and $\operatorname{cod} Y$, were constructed in analogy to the construction of pMRP306 which has previously been used in the investigation of tet $R$ in C. tetani and regulatory genes in C. botulinum [13,14]. DNA segments for anti-sense mRNA production were designed, located in the RR gene of three TCSs (CTC_RS04785, CTC_RS10155, and CTC_RS07315) and in the SHK gene in six other TCSs (CTC_RS13810,CTC_RS02085, CTC_RS04705, CTC_RS06180, CTC_RS05750 and CTC_RS10030) (Table 2).

Table 2. CN655 anti-sense strains, and primers used for the construction of recombinant plasmids generating antisense mRNA. The PCR products from CN655 genome DNA contain a 3'NcoI site and a 5'PstI site and were cloned into pMRP306, a derivative of pAT19 containing the promoter of the iota toxin gene, the cloning sites NcoI-PstI and the 3'part of the iota toxin gene [14]. The resultant antisense RNA plasmids were transformed into CN655 by electroporation. SHK: Sensor Histidine Kinase, RR: Response regulator.

\begin{tabular}{|c|c|c|c|c|c|}
\hline $\begin{array}{c}\text { Isogenic } \\
\text { Antisense } \\
\text { Strains }\end{array}$ & $\begin{array}{l}\text { Target } \\
\text { Gene }\end{array}$ & $S / R$ & Primer & Nucleotide Sequence $\left(5^{\prime}->3\right)$ & $\begin{array}{c}\text { Product } \\
\text { Length }(b p)\end{array}$ \\
\hline CN655/1307 & CTC_p22 & $S$ & $\begin{array}{l}\text { P2020-F } \\
\text { P2021-R }\end{array}$ & $\begin{array}{l}\text { CCGCTGCAGGATAATTTGGGAATGATTATTTTA } \\
\text { GGCCATGGTTAACATATCGTCCATACTC }\end{array}$ & 228 \\
\hline CN655/1308 & CTC_00412 & $S$ & $\begin{array}{l}\text { P2022-F } \\
\text { P2023-R }\end{array}$ & $\begin{array}{c}\text { CCGCTGCAGGAGGTGATTGAAAAATAG } \\
\text { GGCCATGGTAAATCTAACATAGTAAATTTATAC }\end{array}$ & 208 \\
\hline CN655/1309 & CTC_00934 & $S$ & $\begin{array}{l}\text { P2026-F } \\
\text { P2027-R }\end{array}$ & $\begin{array}{l}\text { CCGCTGCAGCAGGGGGTATTTTTGTGTTAAATAATAGG } \\
\text { GGCCATGGCATTGGCATCGCAACATATGCG }\end{array}$ & 236 \\
\hline CN655/1312 & CTC_01211 & $S$ & $\begin{array}{l}\text { P2028-F } \\
\text { P2029-R }\end{array}$ & $\begin{array}{l}\text { CCGCTGCAGGGGGAGACAGTGGTGAAGTTGCG } \\
\text { GGCCATGGGGTTAAAAAATTTTCTTTTATATTTC }\end{array}$ & 223 \\
\hline CN655/1313 & CTC_01951 & S & $\begin{array}{l}\text { P2034-F } \\
\text { P2035-R }\end{array}$ & $\begin{array}{l}\text { CCGCTGCAGGGAAGGTAGAAAATGAAAAGTATAAAG } \\
\text { GGCCATGGCCACATTATCCATTATATTTTCTTC }\end{array}$ & 243 \\
\hline CN655/1419 & CTC_01421 & $\mathrm{R}$ & $\begin{array}{l}\text { P2291-F } \\
\text { P2292-R }\end{array}$ & $\begin{array}{l}\text { CCGCTGCAGGGGAGATTTTGTGAACAACATATT } \\
\text { GGCCATGGTCTGATGCCTTTCTTATTTCTTTAC }\end{array}$ & 242 \\
\hline CN655/1418 & CTC_01260 & CodY & $\begin{array}{l}\text { P2289-F } \\
\text { P2290-R }\end{array}$ & $\begin{array}{c}\text { CCGCTGCAGGAGGAGTTACAAATGTCATCATTATTA } \\
\text { GGCCATGGACTACCTTGTCTCTTACTGTCTG }\end{array}$ & 232 \\
\hline CN655/1472 & CTC_00222 & Spo0 & $\begin{array}{l}\text { P2361-F } \\
\text { P2362-R }\end{array}$ & $\begin{array}{l}\text { CCGCTGCAGGGAGGTATAAAATATATGATA } \\
\text { GGCCATGGTTATTACACTCTTTAAAGGTGAA }\end{array}$ & 225 \\
\hline CN655/1480 & CTC_00194 & $\mathrm{mfd}$ & $\begin{array}{l}\text { P2359-F } \\
\text { P2360-R }\end{array}$ & $\begin{array}{l}\text { CCGCTGCAGGAGGTGAATTTTATTATGAGAT } \\
\text { GGCCATGGAATATTTTTTGCTTCTATATCG }\end{array}$ & 236 \\
\hline
\end{tabular}

Although the growth kinetics of CN655 harboring the empty vector pAT18 (CN655/pAT18) was slightly lower than that of the wt $\mathrm{CN} 655$ during the exponential growth phase and beginning of the stationary phase, the total production of TeNT was slightly higher (Supplementary Materials Figure S1). Both CN655/pAT18 and CN655 wt showed similar growth and toxin production from $72 \mathrm{~h}$ to $144 \mathrm{~h}$ (Supplementary Materials Figure S1). No difference in bacterial size and microscopic morphology was observed between CN655 wt and CN655/pAT18.

Seven CN655 anti-sense strains targeting four TCSs (p1308 targeting CTC_RS02085, p1310 targeting CTC_RS04785, p1311 targeting CTC_RS05750, p1419 targeting CTC_RS07315), and three regulators (p1480 targeting $\mathrm{mfd}$, p1472 targeting spo0A, and p1418 targeting codY), showed similar growth kinetics compared to the control strain CN655/pAT18 (Figure 1). However, growth of strains CN655/p1307 targeting CTC_RS13810, CN655/p1309 targeting CTC_RS04705, CN655/p1312 targeting CTC_RS06180, CN655/p1313 targeting CTC_RS10030, and CN655/p1314 targeting CTC_RS10155 was more abundant than the control strain CN655/pAT18 in the early stationary phase (12-48 h), but the five anti-sense 
strains reached a similar biomass as monitored by $\mathrm{OD}_{600 \mathrm{~nm}}$ than that of the other anti-sense strains at 72-144 h (Figure 1).
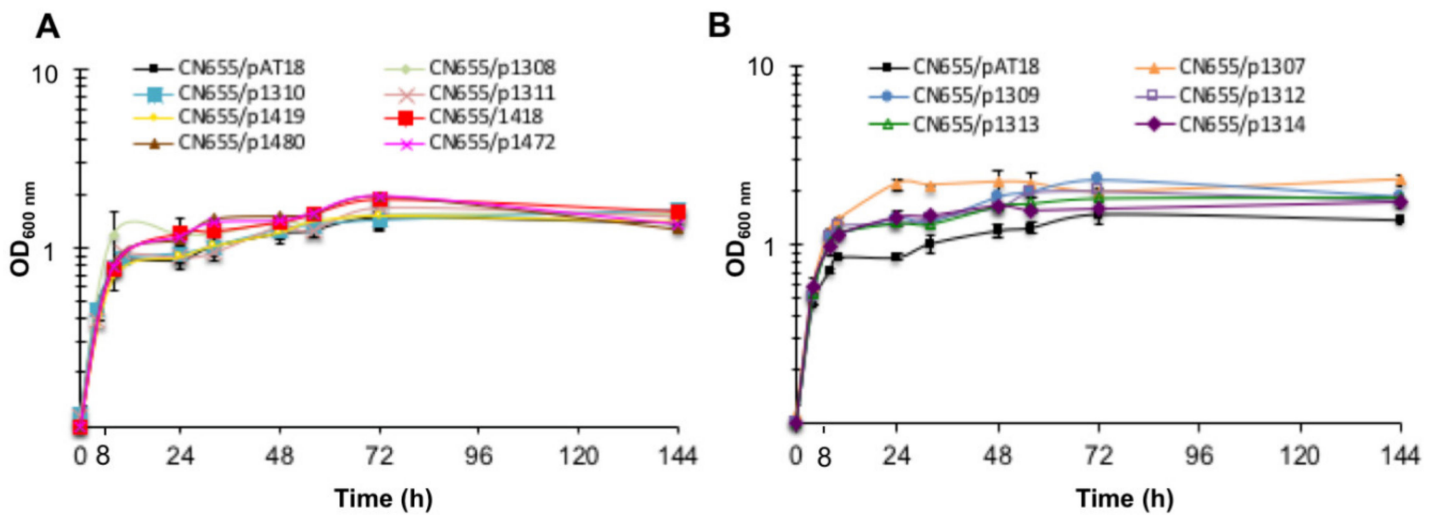

Figure 1. Growth kinetics of C. tetani strain CN655/pAT18 (empty vector) and CN655 antisense strains. (A) CN655/p1308, CN655/p1310, CN655/p1311, CN655/p1419, CN655/p1418, CN655/1480 and CN655/p1472 showed a similar kinetics compared to CN655/pAT18 strain. (B) CN655/p1307, CN655/p1309, CN655/p1312, CN655/p1313 and CN655/p1314 displayed a more abundant growth than CN655/pAT18 in the early stationary phase $(12-48 \mathrm{~h})$. Data are mean values \pm SEM of at least three independent cultures.

\subsection{TeNT Synthesis is Altered in Five TCS Anti-Sense Strains and in the codY Anti-Sense Strain}

Extracellular TeNT concentrations as monitored by enzyme-linked immunosorbent assay (ELISA) in the culture supernatant were reduced in three CN655 anti-sense strains (CN655/p1307, CN655/p1314 and CN655/p1310) as well as in the codY anti-sense strain (CN655/p1418) compared to the control strain CN655/pAT18 (Figure 2A). CN655/p1307, which targets the TCS located on the large tent-containing C. tetani plasmid, and CN655/p1314 targeting the chromosomal CTC_RS10155 TCS, showed a drastic decrease $(65 \%$ to $75 \%)$ in the levels of secreted TeNT. In contrast, CN655/p1310 which targets CTC_RS04785 exhibited a moderate decrease (about 25\%) in secreted TeNT. The codY anti-sense strain (CN655/p1418) showed a significantly lower (50\% to 65\%) TeNT level in the culture supernatant within the first $56 \mathrm{~h}$ of culture and a less pronounced effect ( $20 \%$ to $25 \%$ ) in the late growth phase (Figure 2A). The anti-sense strains CN655/p1308, CN655/p1309, CN655/p1312, CN655/p1313, CN655/p1480 and CN655/p1472 showed no significant difference in the production of extracellular TeNT compared to CN655/pAT18 (Supplementary Figure S1).

Total amounts of produced TeNT (i.e., TeNT in the culture supernatant and intracellular TeNT at the end of culture growth) were significantly decreased in CN655/p1307, CN655/p1314 and in CN655/p1418, whereas no significant difference was observed in CN655/p1310 (Figure 3A).

In contrast, the extracellular and total TeNT concentrations were significantly increased in CN655/p1419 targeting CTC_RS07315 (Figures 2B and 3B). The anti-sense strain CN655/p1311 targeting CTC_RS05750 showed an increase in extracellular TeNT within the first $48 \mathrm{~h}$ of culture, but the total TeNT amount at the end of culture was not significantly different from the control strain (Figure 2, Supplementary Materials Figure S2).

The total production of TeNT was not significantly different from that of the control strain CN655/pAT18 in CN655/p1308, CN655/p1309, CN655/p1312, CN655/p1313, CN655/p1480 and CN655/p1472 (Supplementary Materials Figure S3). 


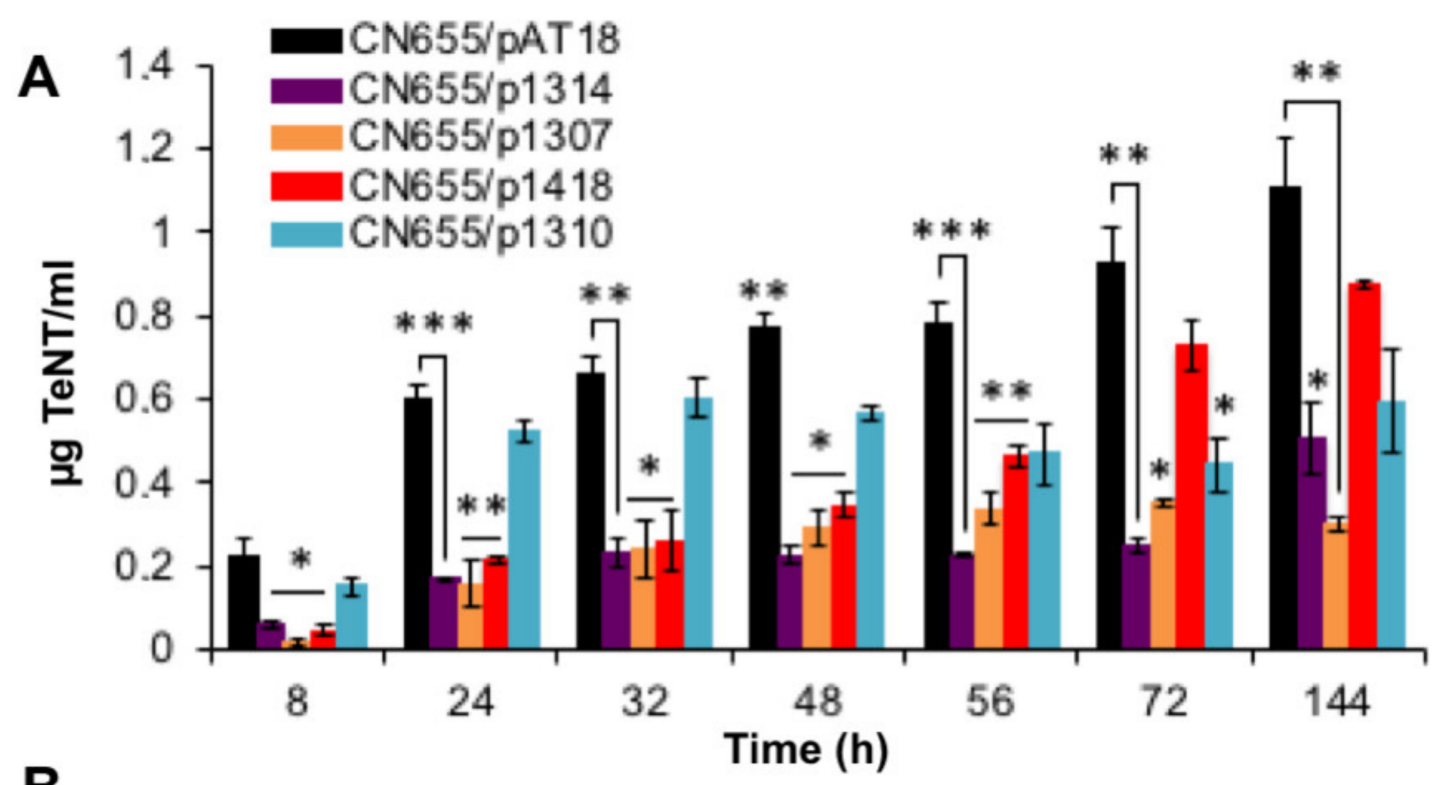

B

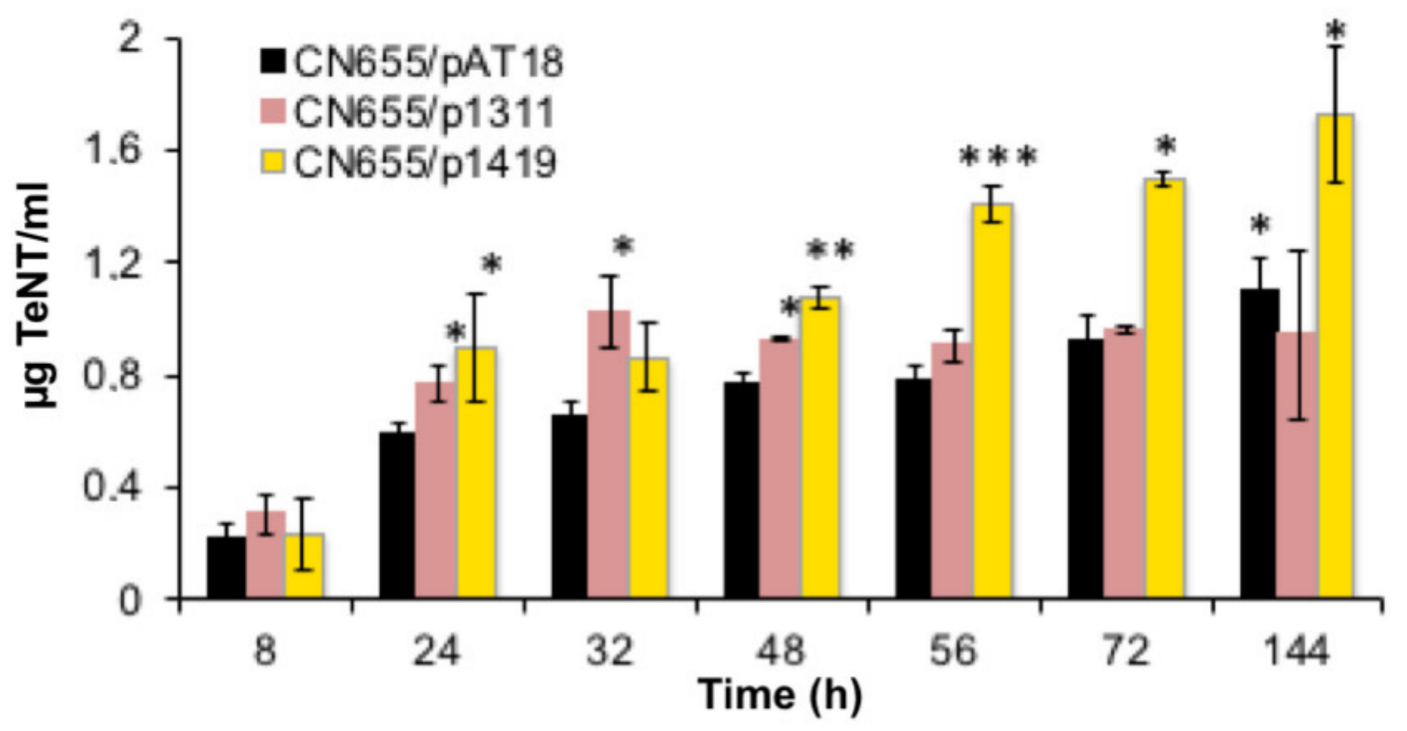

Figure 2. Extracellular tetanus toxin (TeNT) produced by C. tetani CN655/pAT18 (empty vector) and CN655 antisense strains. (A) Extracellular toxin was reduced in the culture supernatant of CN655/p1307, CN655/p1310, CN655/p1314 and CN655/p1418. (B) CN655/p1311 and CN655/p1419 showed elevated extracellular toxin kinetics compared to control strain CN655/pAT18. Statistical significance of differences between control and anti-sense strains is indicated with $p$-values $\left({ }^{*}, p<0.05\right.$; $\left.{ }^{* *}, p<0.01 ;{ }^{* * *}, p<0.001\right)$. Data are mean values \pm SEM of at least three independent cultures. 

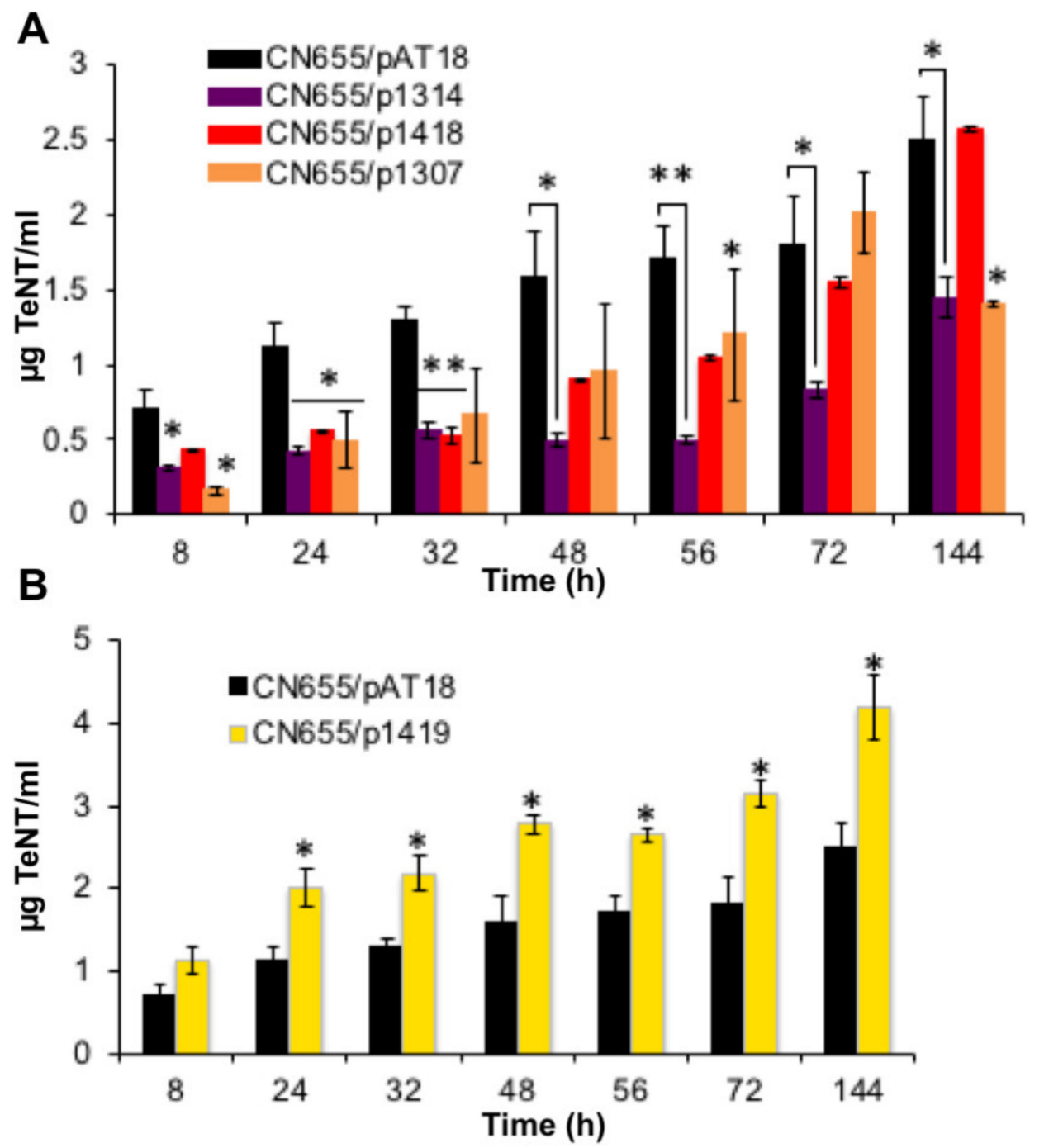

Figure 3. Total tetanus toxin (TeNT) produced by C. tetani CN655/pAT18 (empty vector) and CN655 antisense strains. (A) Total tetanus toxin production was reduced in CN655/p1307, CN655/p1314 and CN655/p1418. (B) CN655/p1419 showed elevated total toxin kinetics compared to control strain CN655/pAT18. Three independent experiments have been done. Statistical significance of differences between control strain and anti-sense strains is indicated with $p$-values $\left({ }^{*}, p<0.05 ;{ }^{* *}, p<0.01\right)$.

\subsection{Five TCSs and codY Control Tent and/or Tetr at the Transcriptional Level}

The transcriptional levels of tent and tet $R$ were monitored by qRT-PCR at $8,24,32$ and $48 \mathrm{~h}$ of culture, which corresponded to the exponential growth phase $(8 \mathrm{~h})$ and early stationary growth phase (12-48 h) (Figure 1). The limit of these analyses is based on the consideration that the copy numbers of the recombinant plasmids are similar in the recombinant strains. Among the TCSs investigated by RNA anti-sense, CN655/p1307 and CN655/p1314 showed a significant reduction of tent and tetR transcription during the 24-48 h growth phase and only a moderate effect at the $8 \mathrm{~h}$ exponential growth phase (Figure 4). A marked reduced transcription of tet $R$ was observed in CN655/p1310 at the $8 \mathrm{~h}$ exponential and 24-32 h early stationary growth phase, whereas tent transcription was not significantly reduced (Figure 4). In contrast, the anti-sense strain CN655/p1311 showed an increase in tent and tet $R$ transcription at the $8 \mathrm{~h}$ exponential growth phase and to a lower extent within the 24-48 $\mathrm{h}$ stationary growth phase (Figure 4). The anti-sense strain CN655/p1419 also exhibited an increased tent transcription level at $8 \mathrm{~h}$ exponential growth phase and at $48 \mathrm{~h}$ of culture, but a decreased transcription of tet $R$ within the 24-32 h early stationary growth phase, albeit to a lower extent than in CN655/p1307 
and CN655/p1314 (Figure 4). This suggests that CTC_ RS07315 (targeted in CN655/p1419) controls tent transcription independently of tetR.

A

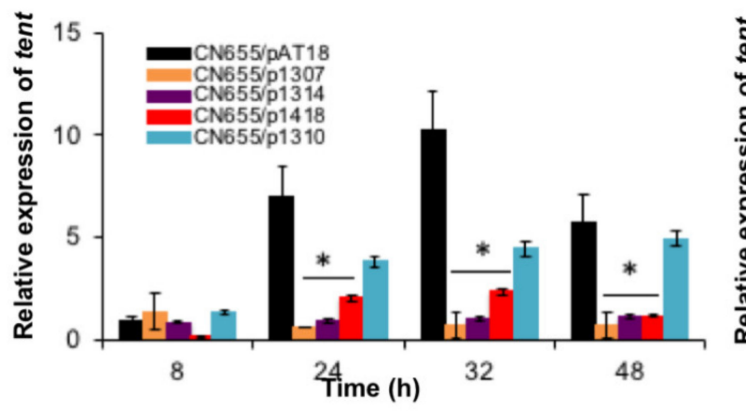

B

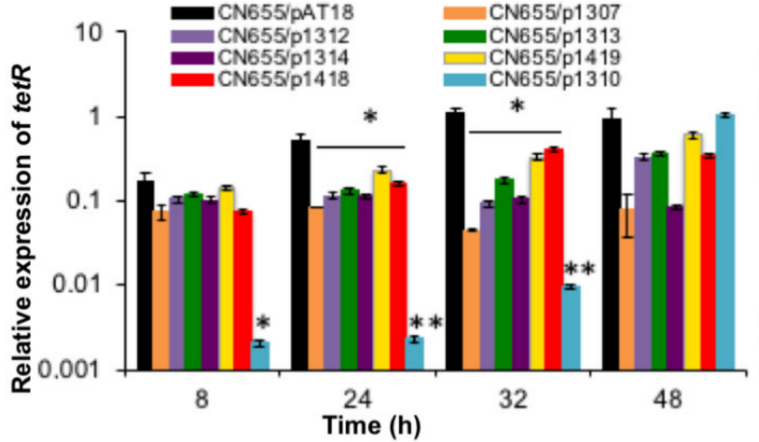

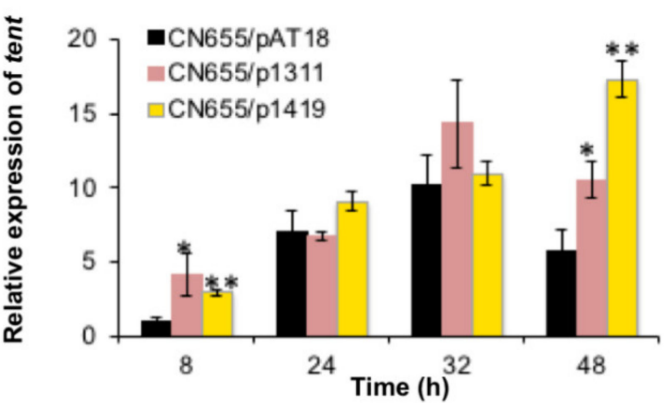

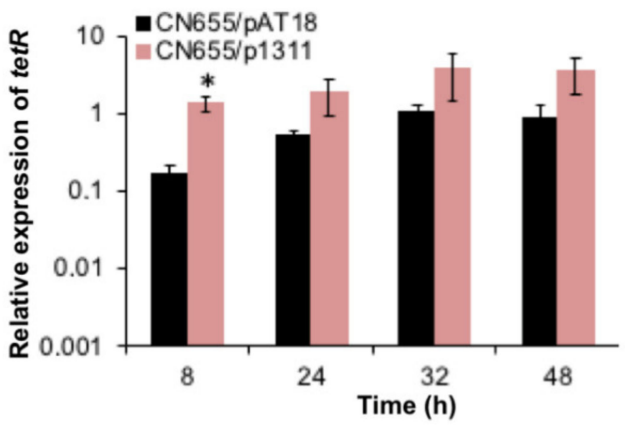

Figure 4. Expression of (A) tent and (B) tetR in CN655/pAT 18 and CN655 antisense strains. (A) The expression of tent was repressed in CN655/p1307, CN655/p1310, CN655/p1314 and CN655/p1418 compared to the control strain CN655/pAT18. For strains CN655/p1311 and CN655/p1419, an increased tent expression was observed. (B) The expression of tetR was repressed in CN655/p1307, CN655/p1310, CN655/p1312, CN655/p1313, CN655/p1314, CN655/p1419 and CN655/p1418. Strain CN655/p1311 showed an increase in tetR expression compared to the control strain CN655/pAT18. Target gene expression was normalized to $r p o B$ and gyrA. Three independent experiments have been done. Statistical significance of differences between control and the anti-sense strains is indicated with $p$-values $(*, p<0.05 ; * *, p<0.01)$.

The transcriptional levels of tent and tetR were not significantly different in CN655/p1308, and CN655/p1309 compared to the control strain CN655/pAT18 (Supplementary Materials Figure S4). Despite a slightly decreased transcription of tetR in CN655/p1312 and CN655/p1313 during the 24-32 h early stationary growth phase (Figure 4), no significant alteration of tent transcription was observed in these strains (Supplementary Materials Figure S3).

The anti-sense strain in which $\operatorname{cod} Y$ was targeted (CN655/p1418), showed a decrease in tent transcription within the 8-48 h culture and a moderate decrease in tet $R$ transcription (Figure 4).

\subsection{The CTC_RS07315 and CTC_RS04785 Response Regulators as well as Cody Bind to the Tent Promoter}

To identify the mode of action of the positive and negative regulators of tent gene transcription, we investigated their possible direct interaction with tent and/or tet $R$ genes by testing the binding of the regulators to the promoters of tent and tetR. As shown in Figure 5, the CTC_ RS07315 (targeted in CN655/p1419) RR specifically bound to the promoters of both tent and tetR $\left(\mathrm{P}_{\text {tent }}, \mathrm{P}_{\text {tet }}\right)$. The RR CTC_RS04785 (targeted in CN655/p1310) caused a shift in the mobility of $\mathrm{P}_{\text {tent }}$ but not in $\mathrm{P}_{\text {tetR }}$, despite the significant decrease in tet $R$ transcription. In contrast, no specific binding to $\mathrm{P}_{\text {tent }}$ or $\mathrm{P}_{\text {tet } R}$ was observed with the RRs of CTC_RS10155, CTC_RS13805 and CTC_RS05745, albeit they influenced the TeNT synthesis and transcription of tent. As expected, no electrophoretic shift was observed with SHK such as CTC_RS04710. In addition, CodY bound to $\mathrm{P}_{\text {tent }}$ but not to $\mathrm{P}_{\text {tetR }}$. As a positive control, TetR, which has been found to positively regulate tent, was used [13]. 

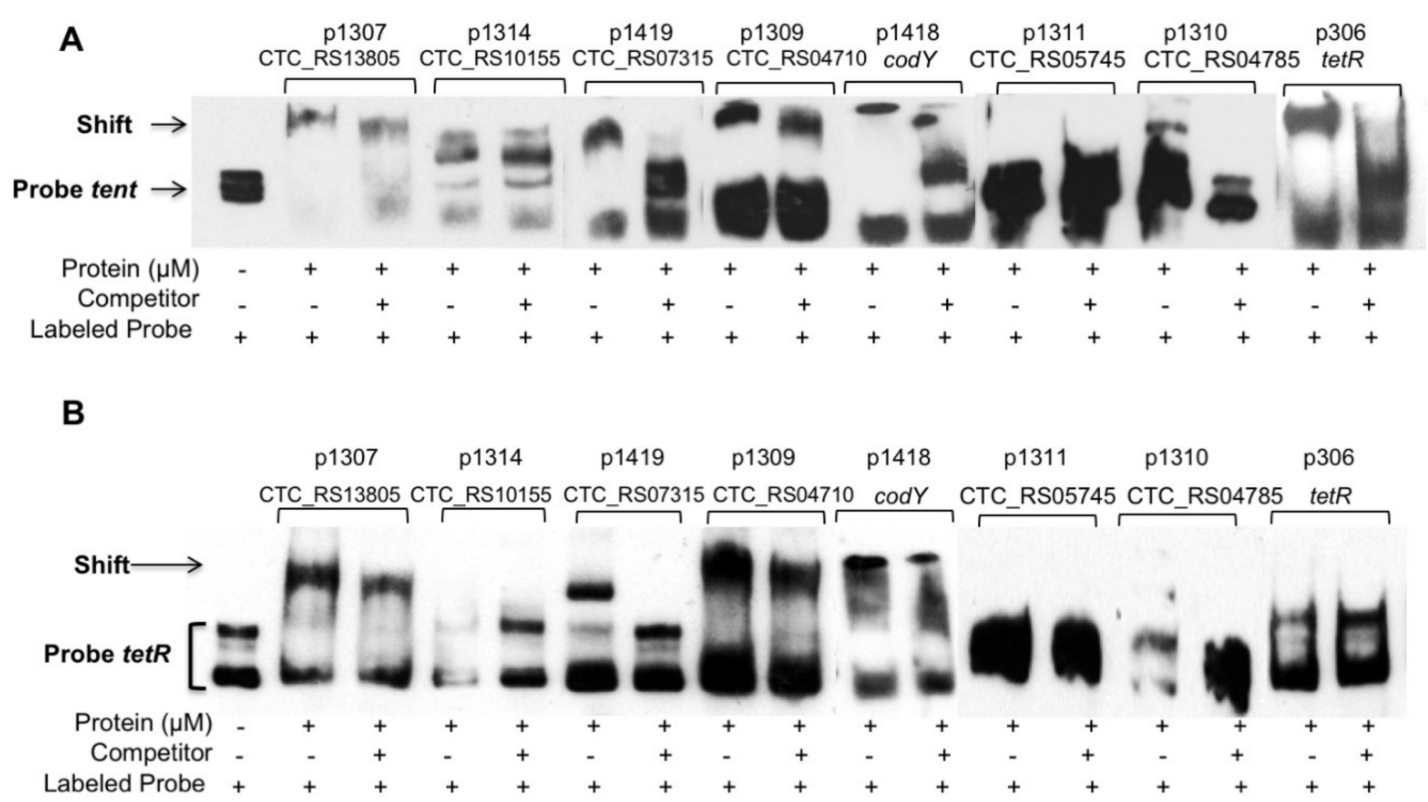

Figure 5. Electrophoretic mobility shift assay (EMSA) showing regulatory protein binding to tent (A) and tet $R(\mathbf{B})$ promoters. Biotin-labeled DNA probes corresponding to the promoter regions of tent $\left(\mathrm{P}_{\text {tent }}\right)$ and tet $R\left(\mathrm{P}_{\text {tet } R}\right)$ were incubated with $5 \mu \mathrm{M}$ of the recombinant proteins CTC_RS13805, CTC_RS10155, CTC_RS07315, CTC_RS04710,CTC_RS05745, CTC_RS04785, CodY and TetR. The specific binding of recombinant proteins to promoter probes resulted in an observable mobility shift when compared to the $\mathrm{P}_{\text {tent }}$ and $\mathrm{P}_{\text {tet }}$ alone. Competition assays were performed with a 300-fold excess of unlabeled probe. Specificity of binding to $P_{\text {tent }}$ was confirmed for CTC_RS07315, CTC_RS04785, CodY and TetR. CTC_RS07315 was the only protein showing specific binding to $\mathrm{P}_{\text {tetR }}$. Addition of recombinant proteins, unlabeled promoter probe as cold competitor and labeled promoter probes are indicated. Representative experiments out of three are shown.

\subsection{Inorganic Phosphate $\left(P_{i}\right)$ Influences TeNT Production}

Since two TCSs (CTC_RS05745/CTC_RS05750 and CTC_RS10030/CTC_RS10035) encoded in the C. tetani genome are putatively involved in the control of phosphate uptake and/or metabolism, as judged from their homologies with previously characterized TCSs, we checked the effect of inorganic phosphate $\left(\mathrm{P}_{\mathrm{i}}\right)$ in the culture medium on TeNT synthesis. Therefore, TGY (trpticase/glucose/yeast extract) culture medium containing less than $2 \mathrm{mM} \mathrm{P}_{\mathrm{i}}$ was supplemented with 10 to $60 \mathrm{mM} \mathrm{P} \mathrm{P}_{\mathrm{i}}$. C. tetani growth was similar in TGY supplemented with 10 and $20 \mathrm{mM} \mathrm{P} P_{\mathrm{i}}$ than that in the TGY control medium, but was slightly decreased when supplemented with 40 and $60 \mathrm{mM} \mathrm{P}_{\mathrm{i}}$ (Figure 6). Extracellular and total TeNT production was increased in TGY containing 40 or $60 \mathrm{mM} \mathrm{P} \mathrm{i}_{\mathrm{i}}$, whereas no significant difference in TeNT production was observed in TGY supplemented with 10 or $20 \mathrm{mM} \mathrm{P}$. The highest level of TeNT production occurred when C. tetani was grown in TGY medium with $40 \mathrm{mM} \mathrm{P}_{\mathrm{i}}$ (at least two-fold more extracellular TeNT compared to TGY control medium) (Figure 6).

Expression of tent was increased in TGY medium containing 10 or $20 \mathrm{mM} \mathrm{Pi}$, and to a higher extent when supplemented with 40 or $60 \mathrm{mM} \mathrm{Pi} \mathrm{(Figure} \mathrm{6D).} \mathrm{The} \mathrm{kinetics} \mathrm{of} \mathrm{increased} \mathrm{tent} \mathrm{expression}$ in TGY supplemented with Pi is similar to that in TGY control medium, occurring at the end of the exponential and beginning of the stationary phase growth phases. Expression of tet $R$ was similarly increased in cultures supplemented with $P_{i}$, but mainly within a shorter time duration between 24 and $32 \mathrm{~h}$ of culture (Figure 6E). This suggests that regulation of TeNT expression by inorganic phosphate is independent of tetR. 
A
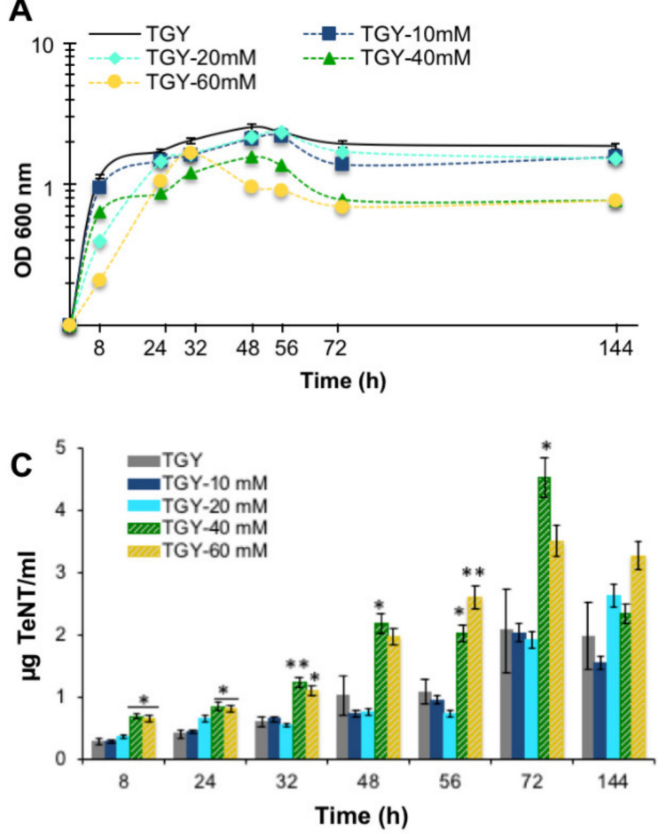

B
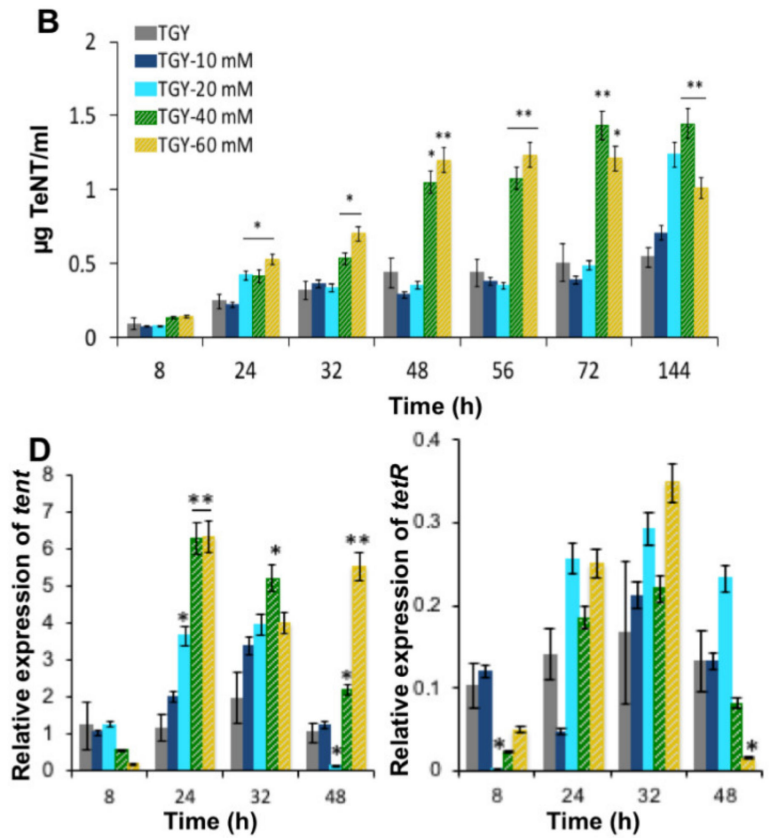

Figure 6. Effect of inorganic phosphate on tetanus toxin (TeNT) production, and tent/tetR expression. (A) Growth kinetics of CN655 in TGY supplemented with various concentrations of inorganic phosphate. (B) Extracellular TeNT levels. (C) Total TeNT levels. (D) Expression of tent and (E) tetR. Data are mean values \pm SEM of at least three independent cultures. ${ }^{*}, p<0.05 ;{ }^{* *}, p<0.01$.

\subsection{Carbonate Stimulates TeNT Synthesis}

High $\mathrm{CO}_{2}$ concentrations $(70 \%)$ have been found to increase the expression of bont and the synthesis of BoNT in C. botulinum group II in contrast to group I strains, where $\mathrm{CO}_{2}$ has no significant stimulatory effect $[27,28] . \mathrm{CO}_{2}$ also increases the toxin production in other bacteria such as Bacillus anthracis, Staphylococcus aureus and Vibrio cholerae [27]. However, the mechanism of the stimulatory effect of $\mathrm{CO}_{2}$ is not well defined. Since C. tetani is phylogenetically related to C. botulinum [29], we tested the influence of carbonate as a nutritional requirement for TeNT synthesis. For that, the TGY medium was supplemented with various $\mathrm{Na}_{2} \mathrm{CO}_{3}$ concentrations, and addition of 50 or $100 \mathrm{mM} \mathrm{Na} \mathrm{CO}_{3}$ did not modify the growth of $\mathrm{C}$. tetani $\mathrm{CN} 655$ (data not shown). We observed a significant stimulatory effect on TeNT synthesis in TGY medium supplemented with $100 \mathrm{mM} \mathrm{Na}_{2} \mathrm{CO}_{3}$ (Figure 7). No synergistic or cumulative effect was detected between the addition of carbonate and $\mathrm{P}_{\mathrm{i}}$ (Figure 7). The $\mathrm{pH}$ at $72 \mathrm{~h}$ of culture was slightly higher ( $\mathrm{pH}$ 7.6) in TGY supplemented with $100 \mathrm{mM} \mathrm{Na}_{2} \mathrm{CO}_{3}$ compared to control TGY ( $\mathrm{pH} 7.0$ ) or TGY with $50 \mathrm{mM} \mathrm{Na}_{2} \mathrm{CO}_{3}$ (pH 7.3). However, the $\mathrm{pH}$ in TGY cultures supplemented with $40 \mathrm{mM} \mathrm{P}_{\mathrm{i}}$ or $100 \mathrm{mM} \mathrm{Na}_{2} \mathrm{CO}_{3} / 40 \mathrm{mM} \mathrm{P}_{\mathrm{i}}$ was not significantly modified ( $\mathrm{pH} 7.0$ and 7.4, respectively), suggesting that the role of $\mathrm{P}_{\mathrm{i}}$ and $\mathrm{Na}_{2} \mathrm{CO}_{3}$ on TeNT synthesis were not $\mathrm{pH}$-dependent.

\subsection{The TCS CTC_RS05745/CTC_RS05750 is Involved in Bacterial Cell Wall Organization}

Since the TCS CTC_RS05745/CTC_RS05750 seemed to be involved in TeNT secretion without controlling the synthesis level of toxin (see above and Figure 2), we investigated the morphology of the strain CN655/p1311 in comparison to the wt CN655 by electron microscopy (Figure 8). Electron microscopic analysis of wt $\mathrm{CN} 655$ and strain $\mathrm{CN655/p1311} \mathrm{showed} \mathrm{a} \mathrm{marked} \mathrm{alteration} \mathrm{of} \mathrm{the} \mathrm{bacterial}$ wall of the mutant strain (Figure 8). In the wt CN655 strain, the layers forming the bacterial wall are well organized. In contrast, in strain CN655/p1311, the bacterial wall appeared disorganized and an abundantly detected diffuse material surrounded the bacteria. The altered bacterial wall of CN655/p1311 might account for the increased extracellular TeNT level. 


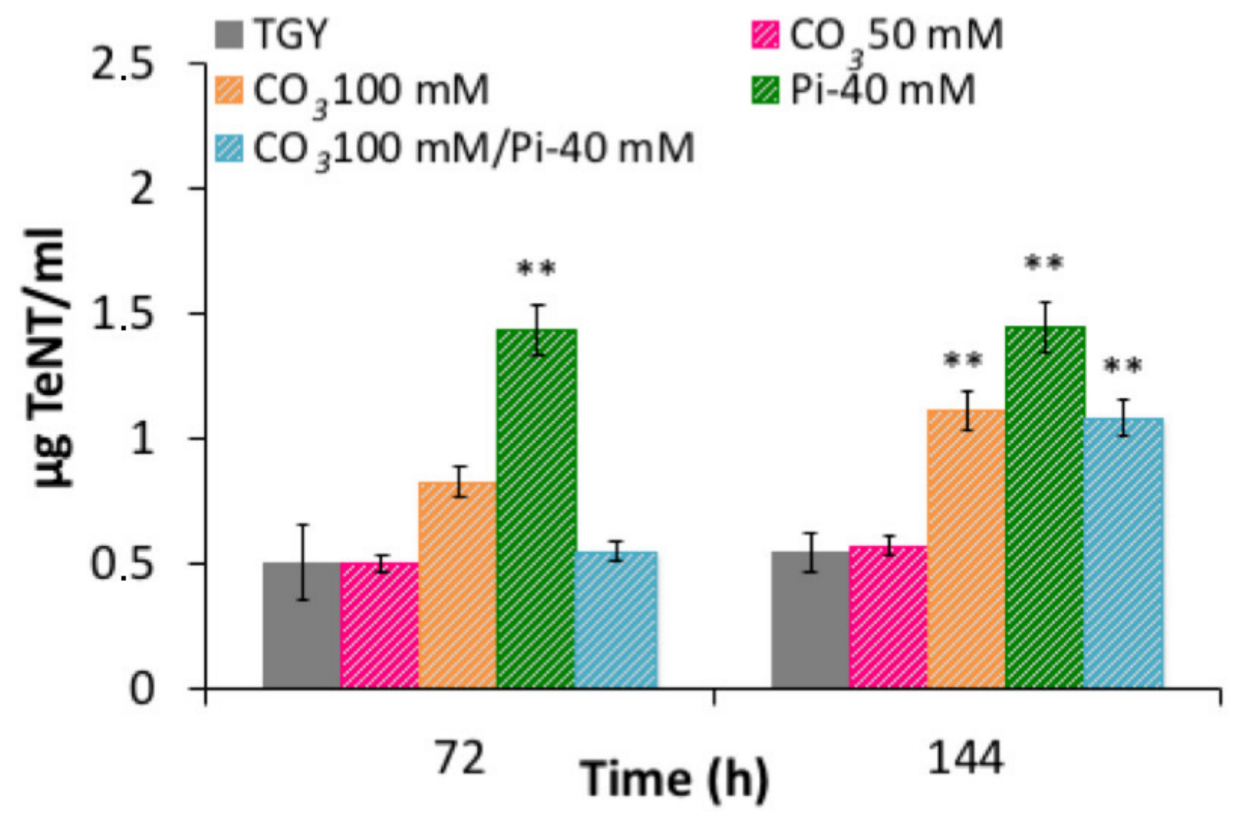

Figure 7. Effects of sodium carbonate and inorganic phosphate on extracellular tetanus toxin (TeNT). C. tetani CN655 was grown in TGY supplemented with either 50 or $100 \mathrm{mM} \mathrm{Na}_{2} \mathrm{CO}_{3}, 40 \mathrm{mM} \mathrm{P}$, or $100 \mathrm{mM} \mathrm{Na} \mathrm{CO}_{3}$ and $40 \mathrm{mM} \mathrm{P}_{\mathrm{i}}$. Extracellular toxin levels were increased in TGY medium supplemented with $40 \mathrm{mM} \mathrm{P} \mathrm{P}_{\mathrm{i}}$ or $100 \mathrm{mM} \mathrm{Na} \mathrm{CO}_{3}$. The addition of both $\mathrm{P}_{\mathrm{i}}$ and $\mathrm{Na}_{2} \mathrm{CO}_{3}$ did not result in a synergistic effect on TeNT production. Data are mean values \pm SEM of at least three independent assays. ${ }^{* *}, p<0.05$.

CN655
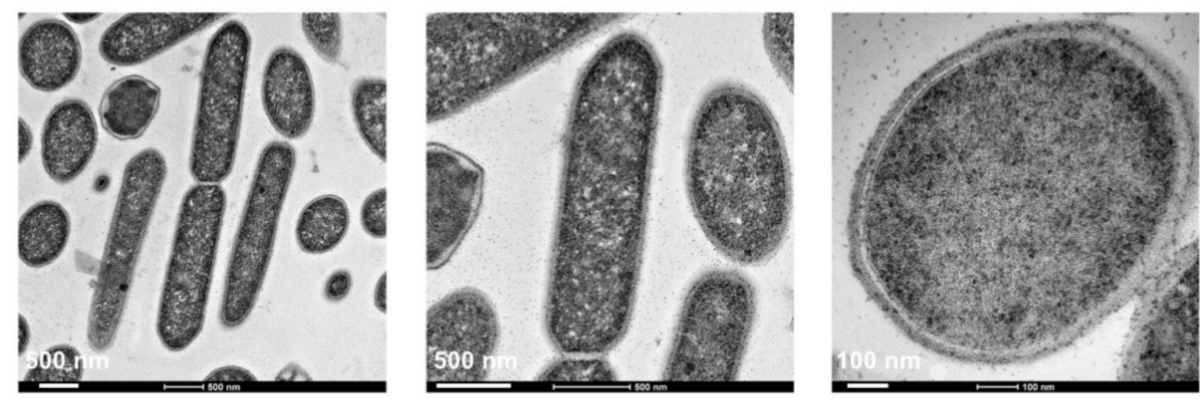

CN655 SEM

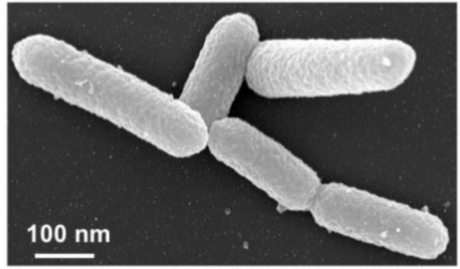

$x 22,000$

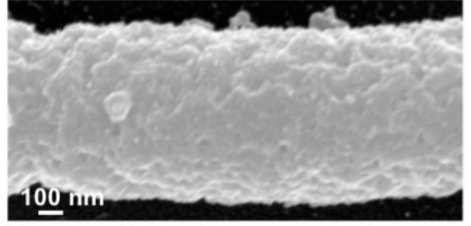

$x 60,000$

Figure 8. Cont. 
CN655I

1311
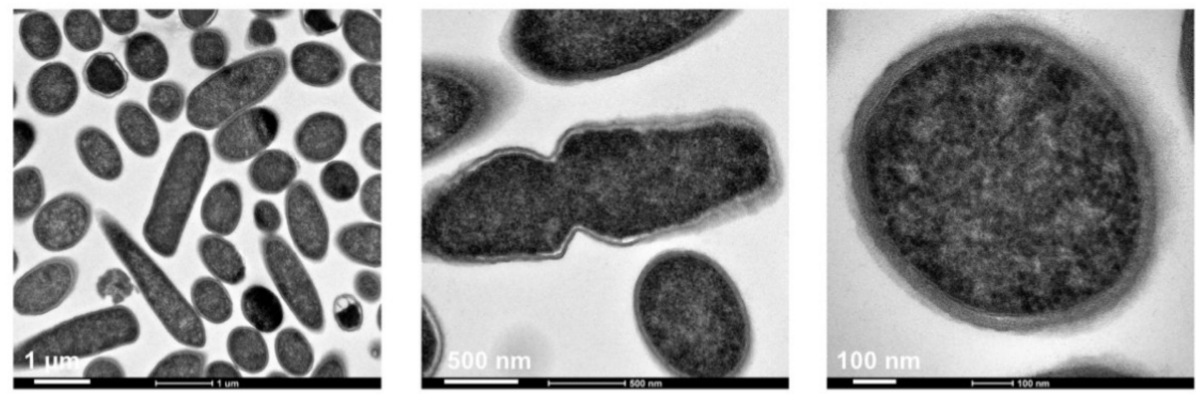

CN655/1311 SEM

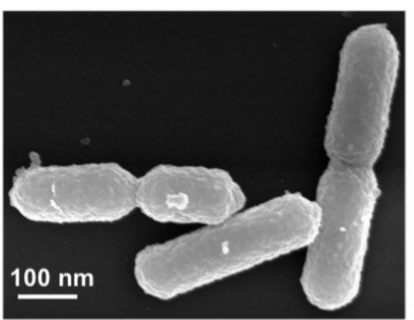

$x 22,000$

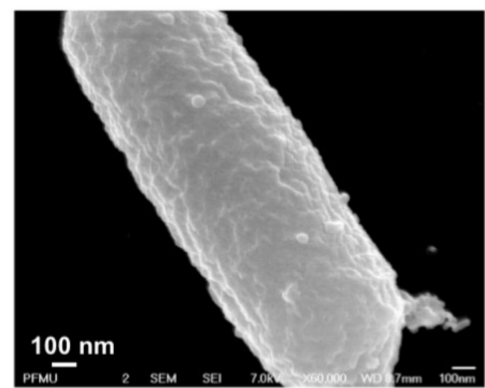

$x 60,000$

Figure 8. Ultrastructural morphology of CN655 and CN655/p1311. Bacteria from 18 h TGY culture were processed for transmission electron microscopy and scanning electron microscopy (SEM). CN655 showed well-delineated bacterial wall layers, whereas the bacterial wall of CN655/p1311 was disorganized with diffuse and enlarged wall layers. CN655/p1311 showed more abundant blebbings on the bacterial surface. About 100 bacterial cells were observed for each preparation.

\section{Discussion}

The mode of TeNT synthesis in C. tetani is still poorly understood. TeNT is usually produced by culturing $C$. tetani in complex media, and variability in TeNT production is a major concern in industrial processes. Carbon and nitrogen sources, notably peptides and amino acids, are important parameters for C. tetani metabolism and TeNT synthesis [6,30-32]. Toxin production in clostridia is typically a complex regulated process $[33,34]$. The gene $t e t R$, which lies directly upstream of tent, was the first regulatory element identified in the regulation of TeNT production. The tet $R$ gene encodes an alternative sigma factor that positively regulates the transcription of tent at the transition phase between the end of the exponential and the beginning of the stationary growth phases [13]. The genome of C. tetani strain E88 was found to contain at least 127 genes that encode putative transcriptional regulators, including 30 TCSs and 29 sigma factors [35]. However, their role in the regulation of TeNT synthesis is not yet known. Here, we have investigated 12 putative regulators. These have been selected based on their homology with regulators that have already been identified to be involved in the toxin regulation in other clostridia such as C. botulinum and C. difficile.

Among the nine TCSs which have been investigated by the RNA anti-sense strategy, two positively regulated the production of TeNT (CTC_13810/CTC_13815 and CTC_RS10150/CTC_RS10155) and one was identified as a negative regulator (CTC_RS07310/CTC_RS07315). Moreover, two other TCSs influenced the extracellular toxin level rather than the total production of TeNT, positively (CTC_RS04780/CTC_RS04785) and negatively (CTC_RS05750/CTC_RS05745) (Figure 9). 


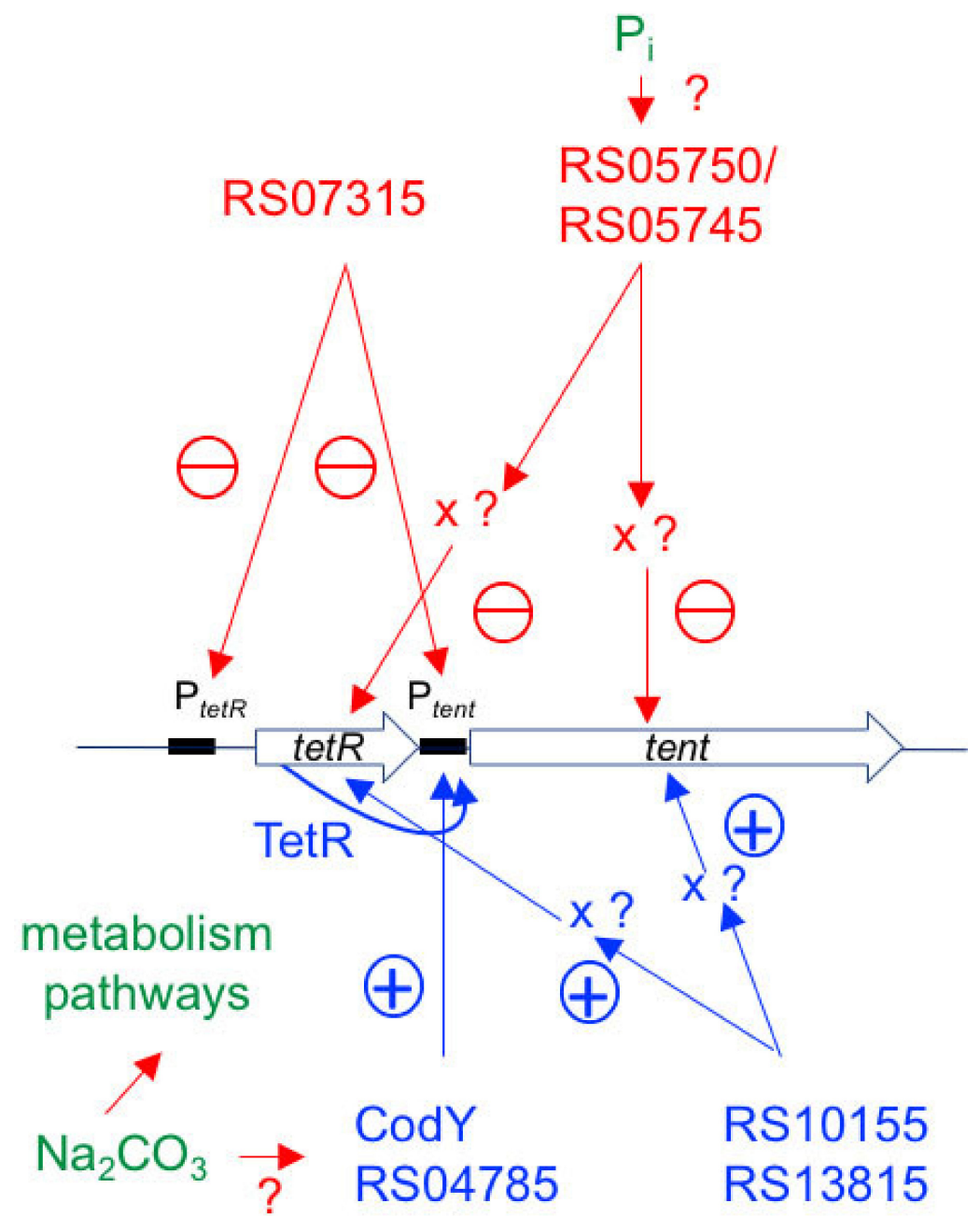

Figure 9. Schematic summary of the regulators of tetanus toxin (TeNT) synthesis of this study. Two two-component systems (TCSs) (RS13815 and RS10155) as well as CodY are positive regulators. They activate the transcription of tet $R$ and tent, only CodY acts directly by interacting with the promoter of tent $\left(\mathrm{P}_{\text {tent }}\right)$. In addition, the TCS RS04785 increases the extracellular TeNT level without or only weakly affecting the total synthesis by interacting with $\mathrm{P}_{\text {tent }}$. One TCS (RS07315) is a negative regulator that interacts with $\left(\mathrm{P}_{\text {tent }}\right)$ and $\left(\mathrm{P}_{\text {tetR }}\right)$. The TCS RS05750 has a moderate negative effect by weakly and indirectly decreasing tent and tet $R$ transcription. Inorganic phosphate (Pi) and carbonate are environmental factors that influence TeNT synthesis through the TCS pathway and/or through the general metabolism.

The TCSs CTC_13810/CTC_13805 and CTC_RS10150/CTC_RS10155 influenced the tent-tetR expression and subsequent TeNT production. However, tent and tet $R$ transcription were not decreased in the exponential growth phase despite a reduction of TeNT production. This might result from a delayed effect of the RNA anti-sense system and/or of unproductive RNA hybridized with the anti-sense RNA. They seem to indirectly control the expression of tent and tet $R$, since the respective RRs bound neither to $P_{\text {tent }}$ nor $P_{\text {tetR }}$.

The TCSCTC_RS13810/CT_RS13805 is the only TCS located on the large tetR-tent operon-containing plasmid, and it is encoded about $25 \mathrm{~kb}$ upstream of tent. The CTC_RS13805 RR belongs to the OmpR family (Table 1) and shares $91 \%$ amino acid identity with a RR of Clostridium lundense but has no homolog in other clostridia or bacteria.

The chromosomally encoded RR CTC_RS10155 is related to the LytR/AlgR family of regulators and is putatively involved in autolysis. This TCS has homologs in C. botulinum and other clostridia. However, the TCS homolog in C. botulinum has no influence on BoNT production [25]. 
The C. botulinum TCS CBO0786/CBO0787 was previously found to repress BoNT synthesis [26]. This TCS has a homolog in C. tetani (CTC_RS07310/CTC_RS07315) with a 58\% identity at the amino acid level of the RR, and it is predicted to be involved in cell division. This $C$. tetani $R R$ was also found to repress TeNT synthesis. Indeed, secreted and total TeNT levels were increased in the anti-sense strain (CN655/p1419). Interestingly, the RR CTC_RS07315 bound to $P_{\text {tent }}$ and $P_{\text {tetR }}$, resulting in a significant decrease in tent expression at the stationary growth phase and a moderate impairment of tet $R$ transcription at late exponential and early stationary growth phases. This suggests that the negative effect on tent transcription results from a direct interaction with $\mathrm{P}_{\text {tent }}$, possibly independent of tet $R$ since the effect on $t e t R$ transcription was weak. The mode of action of CTC_RS07315 RR is likely similar to that of CBO0786, which binds to the ntnh-bont/A and ha operon promoters in C. botulinum and inhibits their transcription, in a botR-independent manner [26].

The TCS CTC_RS05750 also exhibits a negative effect on TeNT secretion, since the respective anti-sense strain (CN655/p1311) showed an increased extracellular TeNT level. The CTC_RS05750 RR belongs to the OmpR family and it is supposed to be involved in the phosphate uptake. CTC_RS05750 moderately inhibits tent and tetR transcription, probably in an indirect manner since in contrast to the RR CTC_RS07315, no binding of CTC_RS05750 RR to $P_{\text {tent }}$ and $P_{t e t R}$ was observed. This TCS probably controls pleiotropic pathways including the assembly of the bacterial wall. The regulatory pathways controlled by CTC_RS05745/CTC_RS05750 are still unknown and this TCS probably has an indirect role in cell wall synthesis. Indeed, a marked alteration of the bacterial wall was observed in CN655/p1311 compared to wt CN655 (Figure 8). The mechanism of TeNT secretion in C. tetani is not yet understood. For several decades, it has been known that $C$. tetani autolysis induces TeNT accumulation in the extracellular medium [36]. Cell wall modification in CN655/p1311 was likely responsible for the increased extracellular TeNT without affecting the total level of TeNT synthesis. CTC_RS05745/CTC_RS05750 is homologous to related TCSs in other clostridia, including C. botulinum. However, the C. botulinum homolog CLC_2386/CLC_2385 (73\% amino acid identity between the corresponding RRs) was not found to be involved in the control of BoNT synthesis [25].

The anti-sense strain CN655/p1310, in which CTC_RS04785 RR was targeted, exhibited a slight decrease in the amount of extracellular TeNT and a marked decrease in tetR expression. However, only a slight decrease in tent expression was observed, albeit CTC_RS04785 RR interacted with $\mathrm{P}_{\text {tent }}$ but not with $\mathrm{P}_{\text {tetR }}, \mathrm{CTC}$ _RS04785 RR has a 34\% amino acid identity with the virulence factor VirR of C. perfringens. VirS-VirR controls 147 genes in C. perfringens including chromosomally-located toxin genes encoding, for example, perfringolysin and alpha-toxin, and plasmid-located toxin genes such as those encoding the Beta2 toxin and collagen-adhesin $[37,38]$. The VirS-VirR system of C. perfringens can positively or negatively regulate its target genes. Some of the target genes contain a VirR-binding box on their promoter and are directly controlled, whereas a regulatory cascade including a non-coding RNA (VR-RNA) is used in the regulation of other genes [39]. The CTC_RS04780/CTC_RS04785 TCS of C. tetani is possibly also involved in a complex network of positive and negative regulatory pathways in C. tetani. Our results suggest that this TCS mainly modulates the secretion, and moderately the synthesis, of TeNT, although CTC_RS04785 was found to bind to the tent promoter and to stimulate tet $R$ transcription.

CodY is a conserved regulator in Gram-positive bacteria, which notably controls metabolism and virulence [17]. In C. botulinum A, CodY positively regulates BoNT/A synthesis through binding to the $n t n h$-bontA operon promoter in a GTP-dependent manner [20]. CodY also activates toxin production and virulence in other Gram-positive bacteria such as Bacillus anthracis, Bacillus cereus, Listeria monocytogenes and several Streptococcus species [40-44]. However, CodY indirectly represses toxin gene expression in C. difficile by interacting with the TcdR promoter [45]. Rapidly metabolizable carbohydrates such as glucose repress toxin production in C. difficile [46], and CodY is a negative regulator of toxin synthesis and virulence in this pathogen [47]. In contrast to C. difficile, TeNT synthesis in C. tetani is not inhibited by glucose. TeNT production is higher when cultivation of $C$. tetani is performed in TGY compared to TY media (Supplementary Materials Figure S5). C. tetani CodY shares 
$81 \%$ amino acid identity with that of C. botulinum type A strain ATCC3502, in which CodY positively controls BoNT/A synthesis [20]. In analogy to its activity in C. botulinum, CodY of C. tetani bound to $\mathrm{P}_{\text {tent }}$ but not to $\mathrm{P}_{\text {tetR }}$, and enhanced tent transcription and subsequent TeNT synthesis. This further supports the interaction between metabolism and toxin production in C. tetani. Since CodY plays a key role in the adaptation to starvation [19], it could control TeNT synthesis via sensing the availability of specific nutrients.

Spo0A is also a master regulator that has been initially identified to control the first steps of sporulation, it also regulates numerous other genes, notably those involved in adaptation to environmental conditions [48]. For example, Spo0A is involved in the switch between the acidogenesis and solventogenesis/sporulation pathways in environmental bacteria such as Clostridium acetobutylicum [49]. Here, Spo0A was not found to control TeNT synthesis, in contrast to its positive impact on BoNT synthesis in C. botulinum $\mathrm{E}$ through binding to the bontE promoter [50]. It is noteworthy that $C$. botulinum $\mathrm{E}$ gene cluster does not contain any bot $R$ or tet $R$ homologs in contrast to $C$. tetani and C. botulinum group I neurotoxin gene clusters. It is questionable whether there is an interplay between Spo0A, BotR/TetR and toxin synthesis. Spo0A controls the sporulation in C. botulinum [23], but we observed no correlation between sporulation and toxin production in C. botulinum A [51]. C. tetani CN655 formed no spore in TGY, albeit this strain synthesized TeNT. CN655 sporulates only poorly (10-100 spores/ml) in the biphasic medium of Anellis et al. [52], and spores were not detected in

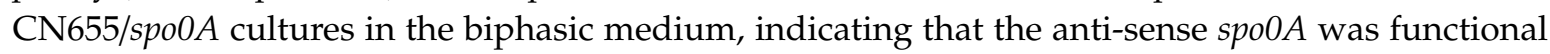
in CN655. In C. difficile, Spo0A differently modulates the toxin synthesis, which depends on the genetic background. In certain $C$. difficile strains such as ribotype 027 strains, Spo0A negatively regulates the production of Toxin A and Toxin B, whereas in other strains, Spo0A has no effect on toxin production [53].

In C. difficile, the protein Mfd is involved in nucleotide excision repair and transcription elongation. This protein has been identified as a positive regulator of Toxin A and Toxin B synthesis. Mfd possibly prevents the inhibitory effect of CodY and CcpA (carbon catabolite protein A) by inhibiting their binding to the toxin gene promoters [24]. Mfd is conserved in C. tetani. However, it had no impact on TeNT synthesis under the conditions tested. In contrast to $C$. difficile, TeNT synthesis is not repressed by rapidly fermentable carbohydrates [54].

Albeit numerous regulatory genes are conserved in clostridia, they have distinct pleiotropic effects in each species. Our data indicate that $C$. tetani retains unique regulatory pathways to control TeNT synthesis, possibly as an adaptation to specific nutrients and/or environmental conditions.

The complex network of toxin regulation in C. tetani raises the question of the environmental factors that trigger the different regulatory components of the network. Since some TCSs are putatively involved in $P_{i}$ uptake and/or metabolism, we tested the influence of $P_{i}$. We observed that an optimum $P_{i}$ concentration around $40 \mathrm{mM}$ significantly increased the transcription of tent and subsequent production of TeNT. In C. perfringens, 20 to $50 \mathrm{mM} \mathrm{P}_{\mathrm{i}}$ concentrations enhance the sporulation and production of $C$. perfringens enterotoxin, the gene expression of which is dependent on sporulation. $P_{i}$ induces spo0A expression and subsequent sporulation $[55,56]$. However, we observed no impact of Pi supplementation on sporulation of CN655 in TGY medium. $P_{i}$ was also found to increase the toxin production in Bacillus thuringiensis [57]. $\mathrm{P}_{\mathrm{i}}$ is a key element in bacterial metabolism; notably, it is incorporated into transcriptional regulatory proteins, and $P_{i}$ homeostasis has a critical adaptive role in bacterial virulence [58]. For example, $\mathrm{P}_{\mathrm{i}}$ availability controls motility, biofilm formation, colonization, induction of virulence factors such as $\mathrm{C}$ phospholipases in Pseudomonas aeruginosa, colonization factor and toxin synthesis in Vibrio cholerae, enteropathogenic and enterohemorrhagic Escherichia coli (review in Reference [58]). In Bacillus anthracis, $\mathrm{P}_{\mathrm{i}}$ starvation enhances spore germination, invasiveness in macrophages and toxin secretion [59]. It can be speculated that $P_{i}$ availability might also facilitate wound colonization by $C$. tetani and in situ TeNT production. The mechanism of $P_{\mathrm{i}}$ in the control of tent transcription is not yet known. It is possibly mediated by TCS such as CTC_RS05745/CTC_RS05750 and CTC_RS10030/CTC_RS10035, which are putatively involved in 
phosphate uptake. Indeed, the corresponding anti-sense strains (CN655/p1311 and CN655/p1313) grown in TGY supplemented with $\mathrm{P}_{\mathrm{i}}(40 \mathrm{mM})$ showed slightly increased extracellular TeNT compared to culture in TGY (Supplementary Materials Figure S6). However, these two TCSs might have pleiotropic effects and indirectly control TeNT synthesis, since they are homologs of the PhoP/PhoR TCS which has been found to control diverse metabolism pathways such as redox homeostasis and adaptation to acidic $\mathrm{pH}$ in Mycobacterium, as well as primary and secondary metabolism pathways under phosphate limitation [60,61].

$\mathrm{CO}_{2}$ at high concentration $(70 \%)$ in the gas phase stimulates bont gene expression and BoNT production, despite a reduced growth rate of $C$. botulinum group II strains, in which the regulatory bot $R$ gene is missing. The mode of action of $\mathrm{CO}_{2}$ is still speculative: it is supposed to dissolve and increase the bicarbonate concentration in the TGY culture medium and subsequently to enhance carboxylation reactions [62]. Increased bicarbonate concentrations were also found to enhance toxin production in $C$. difficile, possibly through biotin-dependent carboxylation [63]. In our conditions, the extracellular TeNT levels were increased in TGY media containing $100 \mathrm{mM} \mathrm{Na}_{2} \mathrm{CO}_{3}$ in a pH-independent manner, whereas no significant difference was observed with $50 \mathrm{mM} \mathrm{Na}_{2} \mathrm{CO}_{3}$ supplementation. The involvement of carbonate in carboxylation reactions is more likely responsible for the regulatory effects on TeNT synthesis than the buffer effect of carbonate.

In conclusion, TeNT synthesis in C. tetani is under the control of a complex network of regulatory elements, including TCSs and regulators of metabolism, as tested by the anti-sense RNA system. However, a more direct approach by deletion of the putative target regulatory genes is required to confirm the regulatory function on TeNT synthesis of these genes. C. tetani and C. botulinum are related clostridial species which synthesize potent neurotoxins in a regulated manner, and their genomes contain numerous TCSs genes (30 in C. tetani and 39 in C. botulinum A [25,35]). Interestingly, albeit most of TCSs genes are homologous in both species, C. tetani and C. botulinum mainly use distinct sets of TCSs in the regulation of toxin synthesis. Among the nine RRs investigated in C. tetani, only one system (CTC_RS07315 in C. tetani and the homolog CBO0786 in C. botulinum) has a similar function in both species, i.e., serves as a negative regulator of toxin synthesis [26]. Four other RRs modulate TeNT synthesis (one acting as negative and three as positive regulators), whereas their homologous counterparts in C. botulinum A have no effect on toxin production [25]. In addition, two TCSs, which positively control BoNT production in C. botulinum, have homologs in C. tetani that do not impact on TeNT synthesis. We hypothesize that $C$. tetani has adapted TeNT synthesis to specific nutritional and environmental requirements. Indeed, C. tetani preferentially uses specific metabolic pathways [35]. Notably, peptides and amino acids are critical substrates for $C$. tetani and specific short peptides from casein digestion are essential for TeNT synthesis [32,35]. Here, we also found that $P_{i}$ and carbonate are additional nutritional requirements for TeNT production. Thereby, TeNT synthesis is dependent of a complex network of regulation linked to $C$. tetani metabolism, in which carbohydrates and $\mathrm{P}_{\mathrm{i}}$ are important elements. A better understanding of the regulation of TeNT synthesis and the underlying environmental factors is required to optimize the toxin production by C. tetani for vaccine production. Albeit tetanus is rare in the developed world, it is still an important cause of deaths in many underdeveloped countries, with 34,000 estimated neonatal tetanus deaths in 2015 [64]. Immunization against TeNT is an efficient method of tetanus prevention, and thus, a 96\% reduction of this disease was achieved since 1988 [64]. Availability of a cheap and efficient tetanus vaccine is an important factor for the eradication of this disease. Unraveling the regulation of TeNT synthesis constitutes the basis for constructing hyperproductive strains.

\section{Materials and Methods}

\subsection{Bacterial Strains and Culture Conditions}

The recombinant strains used in this study are presented in Table 2. Escherichia coli strains were grown in Luria-Bertani (LB) broth and C. tetani CN655 in TGY broth (pH 7.5) containing trypticase 
Peptone (BD Biosciences; $30 \mathrm{~g} / \mathrm{L}$ ), yeast extract (Bacto Yeast Extract, BD Biosciences; $20 \mathrm{~g} / \mathrm{L}$ ), glucose $(5 \mathrm{~g} / \mathrm{L})$ and cysteine, $\mathrm{HCl}(0.5 \mathrm{~g} / \mathrm{L})$ under anaerobic conditions $\left(\mathrm{N}_{2} / \mathrm{CO}_{2} / \mathrm{H}_{2} ; 90: 5: 5\right.$, vol/vol. $)$ at $37^{\circ} \mathrm{C}$. When necessary, erythromycin was added to culture media at 5 or $50 \mu \mathrm{g} / \mathrm{ml}$ for C. tetani and $300 \mu \mathrm{g} / \mathrm{mL}$ for E. coli. C. tetani was grown in TGY with different inorganic phosphate $\left(\mathrm{P}_{\mathrm{i}}\right)$ concentrations by the addition of $\mathrm{Na}_{2} \mathrm{HPO}_{4}$, and/or with sodium carbonate $\mathrm{Na}_{2} \mathrm{CO}_{3}$ (Merck, Guyancourt, France).

Growth kinetics of $C$. tetani CN655 strains in TGY broth culture medium supplemented with erythromycin $(5 \mu \mathrm{g} / \mathrm{mL})$ were monitored by spectrometry at $600 \mathrm{~nm}$ over a $144 \mathrm{~h}$ period.

\subsection{Construction of Vectors Encoding Anti-Sense mRNA for the Different Two-Component Systems (TCS) and Others Regulators}

A DNA fragment of each TCS and regulatory genes studied containing the ribosome binding site (RBS) region was amplified by PCR and inserted in reverse orientation into pAT18, as already described in Reference [14]. DNA segments for anti-sense mRNA production were designed in the RR of three TCS, in the SHK gene of six TCS, as well as in three regulatory genes $(\operatorname{cod} Y, s p o 0 A$ and mfd) (Table 2). The PCR products from CN655 genome DNA contain a 3'NcoI site and a 5' PstI site and were cloned into pMRP306, a derivative of pAT19 containing the promoter of the iota toxin gene, the cloning sites NcoI-PstI and the 3' part of the iota toxin gene [14]. The resultant anti-sense RNA plasmids were transformed into $\mathrm{CN} 655$ by electroporation.

The recombinant plasmids were prepared in Escherichia coli Top10 strain (Dam+, Dcm+) and electroporated into $C$. tetani CN655, with an efficiency of 25-50 transformants per $1 \mu \mathrm{g}$ DNA. Interestingly, no transformant was obtained from plasmids prepared in E. coli BL21 (Dam+, Dcm-) or C2925 (Dam-, Dcm-), indicating that C. tetani CN655 contains a functional Dcm methylase that impairs the transformation of non-DCM-methylated DNA.

\subsection{Tetanus Toxin Assay}

At $8,24,32,48,56,72$ and $144 \mathrm{~h}$ of culture growth, $4 \mathrm{~mL}$ of the culture were removed. The cells were harvested at $10000 \mathrm{rpm}$ for $10 \mathrm{~min}$ at $4{ }^{\circ} \mathrm{C}$, and the supernatants corresponding to the extracellular toxin were filtered $(0.22 \mu \mathrm{m})$ and stored at $-20^{\circ} \mathrm{C}$. For intracellular toxin assay, the pellets were washed twice with distilled water and two osmotic lysis were with TGY containing $20 \mathrm{mg} / \mathrm{mL}$ $\mathrm{NaCl}$ and $13.3 \mathrm{mg} / \mathrm{mL}$ sodium citrate $\left(\mathrm{C}_{6} \mathrm{H}_{5} \mathrm{Na}_{3} \mathrm{O}_{7}, 2 \mathrm{H}_{2} \mathrm{O}\right)$ during $24 \mathrm{~h}$, at $4{ }^{\circ} \mathrm{C}$. after centrifugation, the supernatants containing intracellular toxin were filtered and stored at $-20^{\circ} \mathrm{C}$.

Extracellular and intracellular toxin were monitored by an enzyme-linked immunosorbent assay (ELISA). Wells of microtiter plates (Nunc Maxisorp; Nunc, Roskilde, Denmark) were coated with $100 \mu \mathrm{L}$ of equine anti-tetanus serum (Sanofi Pasteur, FA193727) in $0.05 \mathrm{M}$ carbonate buffer $\mathrm{pH} 9.5$ and incubated at $4{ }^{\circ} \mathrm{C}$ overnight. Plates were washed 3 times with phosphate buffered saline (PBS)-Tween $200.1 \%$ with an automatic plate washer (BioTek, Washer 120, BioTek France, Colmar, France). After blocking with $20 \mathrm{mg} / \mathrm{ml} \mathrm{BSA}$ in carbonate buffer during 30 minutes under agitation, three washes were performed, and $100 \mu \mathrm{l} /$ well of serial two-fold dilutions in PBS-Tween20 0.1\%-BSA 1\% (PBS-T-BSA) of samples were added. The plates were incubated for $1 \mathrm{~h}$ at room temperature with shaking. Tetanus toxin (Sanofi Pasteur, Marcy l'Etoile, France) was used as standard. After three washes, the plates were incubated with $100 \mu \mathrm{L} /$ well of rabbit anti-tetanus serum (1:6400; Sanofi Pasteur $\left.n^{\circ} 7078\right)$ for $1 \mathrm{~h}$ at room temperature, then with $100 \mu \mathrm{l}$ of goat anti-rabbit Ig peroxidase-linked (1:4000, 111-035-006, Jackson Immunoresearch) for $1 \mathrm{~h}$ at room temperature in PBS-T-BSA. For detection, $100 \mu \mathrm{L}$ of $1 \mathrm{mg} / \mathrm{mL}$ ortho-phenylene-diamine (OPD, Sigma) in citrate buffer $\left(0.05 \mathrm{M}, \mathrm{pH} 4.5\right.$ containing $\left.0.06 \% \mathrm{H}_{2} \mathrm{O}_{2}\right)$ was used. The color development was stopped after $8 \mathrm{~min}$ by adding $50 \mu \mathrm{L} 3 \mathrm{M} \mathrm{HCl}$. The absorbance was read on a microplate reader (Biorad, model 680) at 490 and $655 \mathrm{~nm}$.

\subsection{Total RNA Extraction, Reverse Transcription and Quantitative Real-Time PCR Assay}

Total RNA from $C$. tetani strains were extracted at 8, 24, 32 and $48 \mathrm{~h}$ of growth. After centrifugation at $4000 \mathrm{rpm}$ for $15 \mathrm{~min}$ at $4{ }^{\circ} \mathrm{C}$, the culture pellet was mechanically disrupted in the presence of 
silica beads (Lysing Matrix B, MP Biomedicals, Illkirch, France) and buffer RLT (MP Biomedicals) by shaking with a FastPrep apparatus (MP Biomedicals), and RNA total extracted using RNeasy mini kit (Qiagen, Courtaboeuf, France), according to the manufacturer's instructions. The RNA preparations were stored at $-80{ }^{\circ} \mathrm{C}$.

A DNAse treatment with TURBO DNase (Ambion, Thermoscietific, Les Ulis, France was performed following the manufacturer's instructions. The absence of DNA contamination on RNA extracts was checked by real-time PCR (RT-PCR) targeting tent. Total RNA amount was monitored with NanoDrop ND-100 Spectrophotometer. cDNAs were then synthesized from $1 \mu \mathrm{g}$ of total RNA with random primers (pDN6 $5 \mu \mathrm{g} / \mu \mathrm{L}$, Roche, Meylan France) and RNase OUT ${ }^{\mathrm{TM}}$ Recombinant Ribonuclease Inhibitor (Invitrogen, ThermoFischer, Les Ulis, France) and with M-MLV Reverse Tanscriptase kit (Invitrogen), according to the manufacturer's instructions.

RT-PCR was performed in $25 \mu \mathrm{l}$ reaction volume containing $30 \mathrm{ng}$ of cDNAs, $12.5 \mu \mathrm{L}$ of SYBR Green Supermix (Bio-Rad, 2×; $1.25 \mathrm{U}$ iTaq DNA polymerase, $0.4 \mathrm{mM}$ each dNTP, $6 \mathrm{mM} \mathrm{MgCl2,} 20 \mathrm{nM}$ fluorescein, SYBR Green I) and $500 \mathrm{nM}$ gene-specific primers (Table 3) in an iQ iCycler apparatus (Bio-Rad). The reaction was subjected to denaturation at $95^{\circ} \mathrm{C}$ for $3 \mathrm{~min}$ followed by 40 cycles of denaturation at $95^{\circ} \mathrm{C}$ for $10 \mathrm{~s}$, annealing/elongation at $61.7^{\circ} \mathrm{C}$ for $30 \mathrm{~s}$ for rpoB and tent genes and $65.1^{\circ} \mathrm{C}$ for $g y r A$ and tet $R$ genes. Then, a dissociation stage of 65 to $95^{\circ} \mathrm{C}$ with a heating rate of $0.5^{\circ} \mathrm{C}$ per $10 \mathrm{~s}$ was performed to establish a melting curve to confirm the specificity of the RT-PCR reaction for each primer pair.

The relative cDNA quantity of each sample was determined with the threshold cycle [ $\Delta \Delta \mathrm{CT}]$ method (Analysis of Relative Gene Expression Data Using Real-Time Quantitative PCR and the $2 \Delta \Delta C T$ method). cDNA quantity of the tent and tetR gene was normalized to the quantity of cDNA of the rpoB and gyrA gene.

Table 3. Primers used for qRT-PCR, protein expression and promoter regions of tent and tetR for EMSA experiments.

\begin{tabular}{|c|c|c|c|}
\hline Target Gene & Primer & Nucleotide Sequence $\left(5^{\prime}->3\right)$ & $\begin{array}{c}\text { Product } \\
\text { Length (bp) }\end{array}$ \\
\hline \multicolumn{4}{|l|}{ qRT-PCR } \\
\hline \multirow[t]{2}{*}{ tent } & P1714-F & CCAAGGTGCACAAGGAATTT & 146 \\
\hline & P1715-R & CAATGTTTAATGCGGGTCCT & \\
\hline \multirow[t]{2}{*}{ tetR } & P1726-F & GTTGCTCAAATTATTTAAACTTCGAA & 115 \\
\hline & P1727-R & GCTATATCACATTCTTTCATATCTTCAАA & \\
\hline \multirow[t]{2}{*}{ rpoB } & P2142-F & TTGAAGAATGTAAAGAGAGAGATGCTAC & 118 \\
\hline & P2143-R & GGGAAGTCACCCATAAAGACA & \\
\hline \multirow[t]{2}{*}{ gyrA } & $\mathrm{P} 2146-\mathrm{F}$ & AAGATGATGTAGCAGTAAGTATGGA & 98 \\
\hline & P2147-R & CTCTGAAGCCAATGTCCTTTT & \\
\hline \multirow{3}{*}{ CTC_p21 } & & Recombinant protein expression & \\
\hline & P2349-F & CGCCGCGGATCCATGTATAAGATATTGATTGTTGAA & 711 \\
\hline & P2350-R & CCGCCGGAATTCTTACACCTGAAATAAACGATAGCC & \\
\hline \multirow[t]{2}{*}{ CTC_01979 } & P2351-F & CGCCGCGGATCCATGAACAAAATAAATTGTGTAATAATA & 792 \\
\hline & P2352-R & CCGCCGGAATTCTTAAAAATCTAATATGTCCTTTAAGTG & \\
\hline \multirow[t]{2}{*}{ CTC_01421 } & P2353-F & CGCCGCGGATCCGTGAACAACATATTGTTAGTTGAA & 717 \\
\hline & P2354-R & CCGCCGGAATTCCTATTTATTAATTTCGTAGTTCCACCT & \\
\hline \multirow[t]{2}{*}{$\operatorname{cod} \mathrm{Y}$} & P2355-F & CGCGGATCCATGTCATCATTATTAGAGAAG & 801 \\
\hline & P2356-R & CCGCCGGAATTCTTACTTAATTTTTTTCAATTCCTC & \\
\hline \multirow[t]{2}{*}{ CTC_00935 } & P2357-F & CGCGGATCCGTGTGTAGAGTAGTGCTT & 759 \\
\hline & P2358-R & CCGCCGGAATTCTTATACTTTTTTATTATTCAC & \\
\hline \multicolumn{4}{|l|}{ EMSA } \\
\hline \multirow[t]{2}{*}{ Ptent } & P2365-F & (5'-end labelled biotin) GGTGGCTCCATCATAATAATTGTAT & 359 \\
\hline & P2366-R & (5'-end labelled biotin) GGTTTTAGCATTAAAAAAATTAGAACCTA & \\
\hline \multirow[t]{2}{*}{ PtetR } & P2363-F & (5'-end labelled biotin) CAGTATTTTTGAAATGTATAATAATTACTTC & 316 \\
\hline & P2364-R & (5'-end labelled biotin) CGGTTCTCTTAATTTAGTAATATCAATAT & \\
\hline
\end{tabular}

$F$, forward; $R$, reverse. 


\subsection{Expression and Purification of Recombinant Proteins}

The genes ctc_p21,ctc_01979, ctc_1421,ctc_00935, codY and tetR were PCR-amplified from the genome of $C$. tetani $\mathrm{CN} 655$, with primers (Table 3), adding a BamHI site at the 5'end and an EcoRI at the $3^{\prime}$ end. PCR products were digested with appropriate restriction enzymes and the resulting products were cloned into a pCR2.1 vector and subcloned into pET28a (Novagen, Merck, Guyancourt, France) for the expression of N-terminal 6-histidine proteins. The resulting constructions were transformed in E. coli BL21DE3, according to the manufacturer's instructions.

Recombinant proteins were purified by affinity chromatography employing the TALON cobalt affinity resin (Clontech Laboratoires, Saint Germaine n Laye, France) in accordance with the standard protocol provided by the manufacturer. Briefly, to induce expression of recombinant proteins, clones were grown in 1 litter of LB supplemented with $50 \mu \mathrm{g} / \mathrm{mL}$ kanamycin at $37{ }^{\circ} \mathrm{C}$ to an optical density at $600 \mathrm{~nm}$ of $0.6-0.8$. Protein expression was then induced by the addition of isopropyl- $\beta$-D-thiogalactopyranoside (IPTG) at a final concentration of $0.5 \mathrm{mM}$ and the growth was continued overnight at $18^{\circ} \mathrm{C}$. the bacteria were collected by centrifugation, suspended in $\mathrm{PBS}$ pH 8.0 containing $10 \mathrm{mM}$ imidazole and protease inhibitors (EDTA free protease inhibitor cocktail, Roche), and lysed by sonication. The recombinant proteins were eluted with $100 \mathrm{mM}$ imidazole and dialyzed overnight against PBS and then frozen at $-80{ }^{\circ} \mathrm{C}$ for storage. Quantification of the protein was done using the Bradford reagent (BioRad, Marnes La Coquette, France), following the manufacturer's instructions. Aliquots of fractions were analyzed on $12 \%$ sodium dodecyl sulfate-polyacrylamide gel electrophoresis (SDS-PAGE).

\subsection{Electrophoretic Mobility Shift Assay (EMSA)}

A $359 \mathrm{bp}$ fragment covering tent promoter $\left(\mathrm{P}_{\text {tent }}\right.$ probe) and a $316 \mathrm{bp}$ fragment covering tet $R$ promoter $\left(\mathrm{P}_{\text {tet } R}\right)$ were amplified by PCR using $5^{\prime}$-end biotin-labeled primers (Table 3$)$. Binding reactions were carried out for $1 \mathrm{~h}$ at room temperature using $5 \mu \mathrm{M}$ of recombinant proteins, 5 '-end biotin-labeled probe at $0.2 \mathrm{nM}$ for $\mathrm{P}_{\text {ten }} t$ and $0.1 \mathrm{nM}$ for $\mathrm{P}_{\text {tet } R}, 50 \mathrm{ng} / \mu \mathrm{L}$ of poly (dI-dC), $2.5 \%$ glycerol and $5 \mathrm{mM} \mathrm{MgCl}_{2}$ in binding buffer. Competition assays for binding specificity were performed with a 300-fold excess of unlabeled specific probe.

Reactions were separated on a 5\% native polyacrylamide gel, run in $0.5 \times$ Tris-borate buffer-EDTA (TBE) at $4{ }^{\circ} \mathrm{C}$ for $1 \mathrm{~h}$ at $110 \mathrm{~V}$ and electrotransferred to a positively charged nylon membrane (Amersham) at $380 \mathrm{~mA}$ for $30 \mathrm{~min}$. Transferred DNAs were cross-linked to membranes with UV light. The biotin-labeled DNAs were detected with the LightShift Chemiluminescent EMSA kit (Pierce, ThermoFischer, Les Ulis, France) according the manufacturer's specifications.

\subsection{Electron Microscopy}

Bacteria from $18 \mathrm{~h}$ culture were mixed $\mathrm{V} / \mathrm{V}$ with a fixative solution containing $5 \%$ glutaraldehyde (GA) in 0.2 M PHEM buffer pH 7.2 (60 mM Pipes, 25 mM Hepes, 10 mM EGTA, 2 mM MgCl 2 ) and incubated for $1 \mathrm{~h}$. Samples were washed twice in PBS prior to performing a high-pressure (>2000 bar) freezing in 1-hexadecane using a BAL-TEC HPM 010 (LEICA). Freeze substitution was done with $2 \% \mathrm{OsO}_{4}$ and $0.5 \%$ Uranyl Acetate in acetone followed by several steps: $-90{ }^{\circ} \mathrm{C}$ for $42 \mathrm{~h}$, warmed up to $-30{ }^{\circ} \mathrm{C}\left(5^{\circ} \mathrm{C} / \mathrm{h}\right)$, incubation for $12 \mathrm{~h}$, warmed up to $0^{\circ} \mathrm{C}\left(10{ }^{\circ} \mathrm{C} / \mathrm{h}\right)$ and incubation for $1 \mathrm{~h}$. Then, samples were washed with acetone on ice and incubated with increasing low-viscosity embedding media SPURR's kit (EMS ref. 14300)/acetone mixture (1:4) for $3 \mathrm{~h}, 1: 1$ over-night, 3:1 during the day, 9:1 over-night, SPURR resin for the day and over-night. The samples were then placed into flat tubes infiltrated with pure SPURR resin prior to polymerization at $60{ }^{\circ} \mathrm{C}$ for $48 \mathrm{~h}$. Sections $(60-70 \mathrm{nM})$ were obtained on a FC6/UC6 ultramicrotome (Leica, Wetzlar, Germany), transferred on 200 Mesh Square Copper grids coated with formvar and carbon (CF-200-Cu50, Delta Microscopy). Samples were stained with $4 \%$ uranyl acetate and counterstained with lead citrate. Images were recorded with 
TECNAI SPIRIT 120 kv (with a bottom-mounted EAGLE 4K x 4K Camera, ThermoFisher Scientific, Waltham, MA, USA).

For scanning electron microscopy (SEM), the samples dehydrated with ethanol were dried with $\mathrm{CO}_{2}$, and then sputtered with $20 \mathrm{~nm}$ gold palladium with a GATAN Ion Beam Coater and were examined with a JEOL JSM 6700F field emission scanning electron microscope operating at $7 \mathrm{Kv}$. Images were acquired with the upper SE detector (SEI).

\subsection{Statistical Analysis}

Values throughout are expressed as means \pm standard error of the mean. Differences in the different anti-sense strains were assessed using unpaired Student's t-test, where statistical significance is assumed for ${ }^{*} p<0.05,{ }^{* *} p<0.01$ and ${ }^{* *} p<0,001$.

Supplementary Materials: The following are available online at http://www.mdpi.com/2072-6651/12/5/328/s1: Figure S1: Growth kinetics and tetanus toxin (TeNT) production in CN655 wt and CN655/pAT18. Growth kinetics (A) of CN655/pAT18 was slightly lower than that of CN655 wt during the first $56 \mathrm{~h}$, but the total production of TeNT (B) was slightly higher. In the stationary phase from 72 to $144 \mathrm{~h}$, growth kinetics and total TeNT production were similar in both CN655/pAT18 and CN655 wt, Data are mean values \pm SEM of at least three independent cultures. Figure S2: Extracellular tetanus toxin (TeNT) produced by CN655/pAT18 (empty vector) and CN655 anti-sense strains showing no significant difference. CN655/p1308, CN655/p1309, CN655/p1312, CN655/p1313, CN655/p1472 and CN655/p1480 showed no significant difference in extracellular levels of TeNT compared to CN655/pAT18. Data are mean values \pm SEM of at least three independent cultures. Figure S3: Total tetanus toxin (TeNT) produced by CN655/pAT18 (empty vector) and CN655 anti-sense strains showing no significant difference. CN655/1308, CN655/p1309, CN655/p1310, CN655/p1311, CN655/p1312 and CN655/p1313 showed no significant difference in total TeNT levels compared to CN655/pAT18. Data are mean values \pm SEM of at least three independent cultures. Figure S4: Expression of (A) tent and (B) tetR in CN655/pAT18 and CN655 anti-sense strains showing no significant difference. (A) CN655/p1308, CN655/p1309, CN655/p1312 and CN655/p1313 showed no significant difference in tent expression compared to CN655/pAT19. (B) CN655/p1308 and CN655/p1309 showed no significant difference in tetR expression compared to CN655/pAT19. Data are mean values \pm SEM of at least three independent cultures. Figure S5: Growth kinetics and tetanus toxin (TeNT) production in CN655 wt in TGY versus TY culture medium. The presence of glucose $(5 \mathrm{~g} / \mathrm{L})$ in culture medium (TGY) induced a slightly increased growth and a more than two-fold extracellular TeNT compared to TY medium without supplementation in glucose. Data are mean values \pm SEM of at least three independent cultures. Figure S6: Extracellular tetanus toxin (TeNT) produced by CN655/p1311 and CN655/p1313 grown in TGY supplemented with inorganic phosphate. CN655/p1311 and CN655/p131 were grown in TGY and in TGY supplemented with $40 \mathrm{mM} \mathrm{Na}_{2} \mathrm{HPO}_{4}$. Extracellular TeNT was monitored by ELISA. Data are mean values \pm SEM of at least three independent assays.

Author Contributions: D.C.-M., H.B., M.R.P. conceived and designed the experiments; D.C.-M., H.B., M.R.P., C.D., G.H., O.G., C.S., C.T. performed the experiments; D.C.-M., H.B., M.R.P. analyzed the data; L.P., D.G., F.B., V.C., S.D. contributed reagents/materials/analysis tools; M.R.P., H.B. wrote the manuscript. All authors have read and agreed to the published version of the manuscript.

Funding: This research was funded by grant from Sanofi-Pasteur, Marcy l'Etoile and by Institut Pasteur, Paris.

Conflicts of Interest: LP, DG, FB, VC, and SD were employed by the company Sanofi-Pasteur. The remaining authors declare that the research was conducted in the absence of any commercial or financial relationships that could be construed as a potential conflict of interest.

\section{References}

1. Popoff, M.R.; Mazuet, C.; Poulain, B. Botulism and tetanus. In The Prokaryotes: Human Microbiology, 4th ed.; Springer: Berlin/Heidelberg, Germany, 2013; Volume 5, pp. 247-290.

2. Bercsenyi, K.; Schmieg, N.; Bryson, J.B.; Wallace, M.; Caccin, P.; Golding, M.; Zanotti, G.; Greensmith, L.; Nischt, R.; Schiavo, G. Tetanus toxin entry. Nidogens are therapeutic targets for the prevention of tetanus. Science 2014, 346, 1118-1123. [CrossRef] [PubMed]

3. Rossetto, O.; Scorzeto, M.; Megighian, A.; Montecucco, C. tetanus neurotoxin. Toxicon 2013, 66, 59-63. [CrossRef] [PubMed]

4. Schmieg, N.; Berscenyi, K.; Schiavo, G. Uptake and transport of clostridial neurotoxins. In The Comprehensive Sourcebook of Bacterial Protein Toxins, 4th ed.; Alouf, J., Ladant, D., Popoff, M.R., Eds.; Elsevier: Amsterdam, The Netherlands, 2015; pp. 337-360.

5. WHO. Tetanus vaccines: WHO position paper-February 2017. Wkly. Epidemiol. Rec. 2017, 92, 53-76. 
6. Licona-Cassani, C.; Steen, J.A.; Zaragoza, N.E.; Moonen, G.; Moutafis, G.; Hodson, M.P.; Power, J.; Nielsen, L.K.; Marcellin, E. Tetanus toxin production is triggered by the transition from amino acid consumption to peptides. Anaerobe 2016, 41, 113-124. [CrossRef] [PubMed]

7. Laird, W.J.; Aaronson, W.; Silver, R.P.; Habig, W.H.; Hardegree, M.C. plasmid-associated toxigenicity in Clostridium tetani. J. Infect. Dis. 1980, 142, 623. [CrossRef] [PubMed]

8. Finn, C.W.; Silver, R.P.; Habig, W.H.; Hardegree, M.C.; Zon, G.; Garon, C.F. The structural gene for tetanus neurotoxin is on a plasmid. Science 1984, 224, 881-884. [CrossRef]

9. Brüggemann, H.; Bäumer, S.; Fricke, W.F.; Wiezr, A.; Liesagang, H.; Decker, I.; Herzberg, C.; Martinez-Arias, R.; Henne, A.; Gottschalk, G. The genome sequence of Clostridium tetani, the causative agent of tetanus disease. ProC. natl. Acad. Sci. USA 2003, 100, 1316-1321. [CrossRef]

10. Bruggemann, H.; Brzuszkiewicz, E.; Chapeton-Montes, D.; Plourde, L.; Speck, D.; Popoff, M.R. Genomics of Clostridium tetani. Res. Microbiol. 2015, 166, 326-331. [CrossRef]

11. Chapeton-Montes, D.; Plourde, L.; Bouchier, C.; Ma, L.; Diancourt, L.; Criscuolo, A.; Popoff, M.R.; Bruggemann, H. The population structure of Clostridium tetani deduced from its pan-genome. Sci. Rep. 2019, 9, 11220. [CrossRef]

12. Fournier, P.E.; Levy, P.Y.; Million, M.; Croce, O.; Blanc-Tailleur, C.; Brouqui, P.; Raoult, D. Genome of a chronic osteitis-causing Clostridium tetani. New Microbes New Infect. 2014, 2, 25-26. [CrossRef]

13. Marvaud, J.C.; Eisel, U.; Binz, T.; Niemann, H.; Popoff, M.R. tetR is a positive regulator of the tetanus toxin gene in Clostridium tetani and is homologous to botR. Infect. Immun. 1998, 66, 5698-5702. [CrossRef] [PubMed]

14. Marvaud, J.C.; Gibert, M.; Inoue, K.; Fujinaga, V.; Oguma, K.; Popoff, M.R. botR is a positive regulator of botulinum neurotoxin and associated non toxic protein genes in Clostridium botulinum A. Mol. Microbiol. 1998, 29, 1009-1018. [CrossRef] [PubMed]

15. Dupuy, B.; Raffestin, S.; Matamouros, S.; Mani, N.; Popoff, M.R.; Sonenshein, A.L. Regulation of toxin and bacteriocin gene expression in Clostridium by interchangeable RNA polymerase sigma factors. Mol. Microbiol. 2006, 60, 1044-1057. [CrossRef] [PubMed]

16. Raffestin, S.; Dupuy, B.; Marvaud, J.C.; Popoff, M.R. BotR/A and TetR are alternative RNA polymerase sigma factors controlling the expression of the neurotoxin and associated protein genes in Clostridium botulinum type A and Clostridium tetani. Mol. Microbiol. 2005, 55, 235-249. [CrossRef] [PubMed]

17. Brinsmade, S.R. CodY, a master integrator of metabolism and virulence in Gram-positive bacteria. Curr. Genet. 2017, 63, 417-425. [CrossRef] [PubMed]

18. Mitrophanov, A.Y.; Groisman, E.A. Signal integration in bacterial two-component regulatory systems. Genes Dev. 2008, 22, 2601-2611. [CrossRef] [PubMed]

19. Stenz, L.; Francois, P.; Whiteson, K.; Wolz, C.; Linder, P.; Schrenzel, J. The CodY pleiotropic repressor controls virulence in gram-positive pathogens. FEMS Immunol. Med. Microbiol. 2011, 62, 123-139. [CrossRef]

20. Zhang, Z.; Dahlsten, E.; Korkeala, H.; Lindström, M. Positive regulation of botulinum neurotoxin gene expression by CodY in Clostridium botulinum ATCC 3502. Appl. Environ. Microbiol. 2014, 80, 7651-7658. [CrossRef]

21. Mascher, G.; Mertaoja, A.; Korkeala, H.; Lindstrom, M. Neurotoxin synthesis is positively regulated by the sporulation transcription factor Spo0A in Clostridium botulinum type E. Environ. Microbiol. 2017, 19, 4287-4300. [CrossRef]

22. Kirk, D.G.; Palonen, E.; Korkeala, H.; Lindstrom, M. Evaluation of normalization reference genes for RT-qPCR analysis of spo0A and four sporulation sigma factor genes in Clostridium botulinum Group I strain ATCC 3502. Anaerobe 2014, 26, 14-19. [CrossRef]

23. Wörner, K.; Szurmant, H.; Chiang, C.; Hoch, J.A. Phosphorylation and functional analysis of the sporulation initiation factor Spo0A from Clostridium botulinum. Mol. Microbiol. 2006, 59, 1000-1012. [CrossRef] [PubMed]

24. Willing, S.E.; Richards, E.J.; Sempere, L.; Dale, A.G.; Cutting, S.M.; Fairweather, N.F. Increased toxin expression in a Clostridium difficile mfd mutant. BMC Microbiol. 2015, 15, 280. [CrossRef] [PubMed]

25. Connan, C.; Brueggemann, H.; Mazuet, C.; Raffestin, S.; Cayet, N.; Popoff, M.R. Two-component systems are involved in the regulation of botulinum neurotoxin synthesis in Clostridium botulinum type A strain Hall. PLOS ONE 2012, 7, e41848. [CrossRef]

26. Zhang, Z.; Korkeala, H.; Dahlsten, E.; Sahala, E.; Heap, J.T.; Minton, N.P.; Lindstrom, M. Two-component signal transduction system $\mathrm{CBO} 0787 / \mathrm{CBO} 0786$ represses transcription from botulinum neurotoxin promoters in Clostridium botulinum ATCC 3502. PLoS Pathog. 2013, 9, e1003252. [CrossRef] 
27. Artin, I.; Carter, A.T.; Holst, E.; Lovenklev, M.; Mason, D.R.; Peck, M.W.; Radstrom, P. Effects of carbon dioxide on neurotoxin gene expression in nonproteolytic Clostridium botulinum Type E. Appl. Environ. Microbiol. 2008, 74, 2391-2397. [CrossRef] [PubMed]

28. Artin, I.; Mason, D.R.; Pin, C.; Schelin, J.; Peck, M.W.; Holst, E.; Radstrom, P.; Carter, A.T. Effects of carbon dioxide on growth of proteolytic Clostridium botulinum, its ability to produce neurotoxin, and its transcriptome. Appl. Environ. Microbiol. 2010, 76, 1168-1172. [CrossRef]

29. Lawson, P.A.; Rainey, F.A. Proposal to restrict the genus Clostridium Prazmowski to Clostridium butyricum and related species. Int. J. Syst. Evol. Microbiol. 2016, 66, 1009-1016. [CrossRef]

30. Fratelli, F.; Siquini, T.J.; de Abreu, M.E.; Higashi, H.G.; Converti, A.; de Carvalho, J.C. Fed-batch production of tetanus toxin by Clostridium tetani. Biotechnol. Prog. 2010, 26, 88-92. [CrossRef]

31. Fratelli, F.; Siquini, T.J.; Prado, S.M.; Higashi, H.G.; Converti, A.; de Carvalho, J.C. Effect of medium composition on the production of tetanus toxin by Clostridium tetani. Biotechnol. Prog. 2005, 21, 756-761. [CrossRef]

32. Porfirio, Z.; Prado, S.M.; Vancetto, M.D.C.; Fratelli, F.; Alves, E.W.; Raw, I.; Fernandes, B.L.; Camargo, A.C.M.; Lebrun, I. Specific peptides of casein pancreatic digestion enhance the production of tetanus toxin. J. Appl. Microbiol. 1997, 83, 678-684. [CrossRef]

33. Carter, G.P.; Cheung, J.K.; Larcombe, S.; Lyras, D. Regulation of toxin production in the pathogenic clostridia. Mol. Microbiol. 2014, 91, 221-231. [CrossRef] [PubMed]

34. Connan, C.; Deneve, C.; Mazuet, C.; Popoff, M.R. Regulation of toxin synthesis in Clostridium botulinum and Clostridium tetani. Toxicon 2013, 75, 90-100. [CrossRef] [PubMed]

35. Brüggemann, H.; Gottschalk, G. Insights in metabolism and toxin production from the complete genome sequence of Clostridium tetani. Anaerobe 2004, 10, 53-68. [CrossRef] [PubMed]

36. Mellanby, J. The effect of glutamate on toxin production by Clostridium tetani. J. Gen. Microbiol. 1968, 54, 77-82. [CrossRef]

37. Ohtani, K.; Yuan, Y.; Hassan, S.; Wang, R.; Wang, Y.; Shimizu, T. Virulence gene regulation by the agr system in Clostridium perfringens. J. Bacteriol. 2009, 191, 3919-3927. [CrossRef]

38. Ohtani, K.; Shimizu, T. Regulation of toxin gene expression in Clostridium perfringens. Res. Microbiol. 2015, 166, 280-289. [CrossRef]

39. Ohtani, K.; Shimizu, T. Regulation of Toxin Production in Clostridium perfringens. Toxins 2016, 8, 207. [CrossRef]

40. Feng, L.; Zhu, J.; Chang, H.; Gao, X.; Gao, C.; Wei, X.; Yuan, F.; Bei, W. The CodY regulator is essential for virulence in Streptococcus suis serotype 2. Sci. Rep. 2016, 6, 21241. [CrossRef]

41. Lemos, J.A.; Nascimento, M.M.; Lin, V.K.; Abranches, J.; Burne, R.A. Global regulation by (p)ppGpp and CodY in Streptococcus mutans. J. Bacteriol. 2008, 190, 5291-5299. [CrossRef]

42. Lindback, T.; Mols, M.; Basset, C.; Granum, P.E.; Kuipers, O.P.; Kovacs, A.T. CodY, a pleiotropic regulator, influences multicellular behaviour and efficient production of virulence factors in Bacillus cereus. Environ. Microbiol. 2012, 14, 2233-2246. [CrossRef]

43. Lobel, L.; Sigal, N.; Borovok, I.; Ruppin, E.; Herskovits, A.A. Integrative genomic analysis identifies isoleucine and CodY as regulators of Listeria monocytogenes virulence. PLoS Genet. 2012, 8, e1002887. [CrossRef] [PubMed]

44. Van Schaik, W.; Chateau, A.; Dillies, M.A.; Coppee, J.Y.; Sonenshein, A.L.; Fouet, A. The global regulator CodY regulates toxin gene expression in Bacillus anthracis and is required for full virulence. Infect. Immun. 2009, 77, 4437-4445. [CrossRef] [PubMed]

45. Dineen, S.S.; Villapakkam, A.C.; Nordman, J.T.; Sonenshein, A.L. Repression of Clostridium difficile toxin gene expression by CodY. Mol. Microbiol. 2007, 66, 206-219. [CrossRef] [PubMed]

46. Martin-Verstraete, I.; Peltier, J.; Dupuy, B. The regulatory networks that control Clostridium difficile toxin synthesis. Toxins 2016, 8, 153. [CrossRef] [PubMed]

47. Daou, N.; Wang, Y.; Levdikov, V.M.; Nandakumar, M.; Livny, J.; Bouillaut, L.; Blagova, E.; Zhang, K.; Belitsky, B.R.; Rhee, K.; et al. Impact of CodY protein on metabolism, sporulation and virulence in Clostridioides difficile ribotype 027. PLoS ONE 2019, 14, e0206896. [CrossRef]

48. Kovacs, A.T. Bacterial differentiation via gradual activation of global regulators. Curr. Genet. 2016, 62, 125-128. [CrossRef] 
49. Ravagnani, A.; Jennert, K.C.; Steiner, E.; Grunberg, R.; Jefferies, J.R.; Wilkinson, S.R.; Young, D.I.; Tidswell, E.C.; Brown, D.P.; Youngman, P.; et al. Spo0A directly controls the switch from acid to solvent production in solvent-forming clostridia. Mol. Microbiol. 2000, 37, 1172-1185. [CrossRef]

50. Mascher, G.; Derman, Y.; Kirk, D.G.; Palonen, E.; Lindstrôm, M.; Korkeala, H. The CLO3403/CLO3404 two-component system of Clostridium botulinum E1 Beluga is important for cold shock response and growth at low temperatures. Appl. Environ. Microbiol. 2014, 80, 399-407. [CrossRef]

51. Couesnon, A.; Raffestin, S.; Popoff, M.R. Expression of botulinum neurotoxins A and E, and associated non-toxin genes, during the transition phase and stability at high temperature: Analysis by quantitative reverse transcription-PCR. Microbiology 2006, 152, 759-770. [CrossRef]

52. Anellis, A.; Berkowitz, D.; Kemper, D.; Rowley, D.B. Production of types A and B spores of Clostridium botulinum by the biphasic method: Effect on spore population, radiation resistance, and toxigenicity. Appl. Microbiol. 1972, 23, 734-739. [CrossRef]

53. Mackin, K.E.; Carter, G.P.; Howarth, P.; Rood, J.I.; Lyras, D. Spo0A differentially regulates toxin production in evolutionarily diverse strains of Clostridium difficile. PLOS ONE 2013, 8, e79666. [CrossRef] [PubMed]

54. Bouillaut, L.; Dubois, T.; Sonenshein, A.L.; Dupuy, B. Integration of metabolism and virulence in Clostridium difficile. Res. Microbiol. 2015, 166, 375-383. [CrossRef] [PubMed]

55. Philippe, V.A.; Mendez, M.B.; Huang, I.H.; Orsaria, L.M.; Sarker, M.R.; Grau, R.R. Inorganic phosphate induces spore morphogenesis and enterotoxin production in the intestinal pathogen Clostridium perfringens. Infect. Immun. 2006, 74, 3651-3656. [CrossRef]

56. Paredes-Sabja, D.; Sarker, M.R. Clostridium perfringens sporulation and its relevance to pathogenesis. Future Microbiol. 2009, 4, 519-525. [CrossRef] [PubMed]

57. Kurt, A.; Ozkan, M.; Ozcengiz, G. Inorganic phosphate has a crucial effect on Cry3Aa delta-endotoxin production. Lett. Appl. Microbiol. 2005, 41, 303-308. [CrossRef]

58. Chekabab, S.M.; Harel, J.; Dozois, C.M. Interplay between genetic regulation of phosphate homeostasis and bacterial virulence. Virulence 2014, 5, 786-793. [CrossRef]

59. Aggarwal, S.; Somani, V.K.; Bhatnagar, R. Phosphate starvation enhances the pathogenesis of Bacillus anthracis. Int. J. Med. Microbiol. 2015, 305, 523-531. [CrossRef]

60. Allenby, N.E.; Laing, E.; Bucca, G.; Kierzek, A.M.; Smith, C.P. Diverse control of metabolism and other cellular processes in Streptomyces coelicolor by the PhoP transcription factor: Genome-wide identification of in vivo targets. Nucleic Acids Res. 2012, 40, 9543-9556. [CrossRef]

61. Baker, J.J.; Johnson, B.K.; Abramovitch, R.B. Slow growth of Mycobacterium tuberculosis at acidic $\mathrm{pH}$ is regulated by phoPR and host-associated carbon sources. Mol. Microbiol. 2014, 94, 56-69. [CrossRef]

62. Lovenklev, M.; Artin, I.; Hagberg, O.; Borch, E.; Holst, E.; Radstrom, P. Quantitative interaction effects of carbon dioxide, sodium chloride, and sodium nitrite on neurotoxin gene expression in nonproteolytic Clostridium botulinum type B. Appl. Environ. Microbiol. 2004, 70, 2928-2934. [CrossRef]

63. Karlsson, S.; Burman, L.G.; Akerlund, T. Suppression of toxin production in Clostridium difficile VPI10463 by amino acids. Microbiology 1999, 145, 1683-1693. [CrossRef] [PubMed]

64. Burgess, C.; Gasse, F.; Steinglass, R.; Yakubu, A.; Raza, A.A.; Johansen, K. Eliminating maternal and neonatal tetanus and closing the immunity gap. Lancet 2017, 389, 1380-1381. [CrossRef]

(C) 2020 by the authors. Licensee MDPI, Basel, Switzerland. This article is an open access article distributed under the terms and conditions of the Creative Commons Attribution (CC BY) license (http://creativecommons.org/licenses/by/4.0/). 